Article

\title{
The Origin of Sand and Its Colour on the South-Eastern Coast of Spain: Implications for Erosion Management
}

\author{
Francisco Asensio-Montesinos ${ }^{1}$, Enzo Pranzini ${ }^{2}$, Javier Martínez-Martínez ${ }^{3}$, Irene Cinelli ${ }^{2}$, \\ Giorgio Anfuso ${ }^{1}$ (1) and Hugo Corbí ${ }^{4, *}$ (]) \\ 1 Department of Earth Sciences, Faculty of Marine and Environmental Sciences, University of Cádiz, CASEM, \\ 11510 Puerto Real, Cádiz, Spain; francisco.asensio@uca.es (F.A.-M.); giorgio.anfuso@uca.es (G.A.) \\ 2 Department of Earth Science, University of Florence, Via Micheli 4, 50121 Florence, Italy; \\ enzo.pranzini@unifi.it (E.P.); irene.cinelli@hotmail.it (I.C.) \\ 3 Spanish Geological Survey (IGME), Calle Ríos Rosas, 23, 28003 Madrid, Spain; javier.martinez@igme.es \\ 4 Department of Earth Sciences and the Environment, University of Alicante, Apdo. Correos 99, \\ San Vicente del Raspeig, 03080 Alicante, Spain \\ * Correspondence: hugo.corbi@ua.es
}

Received: 21 December 2019; Accepted: 25 January 2020; Published: 30 January 2020

\begin{abstract}
Sand colour can give important information about mineral composition and, consequently, sediment source areas and input systems. Beach appearance, which is mostly linked to sand colour, has a relevant economic function in tourist areas. In this paper, the colour of 66 sand samples, collected along both natural and nourished beaches in the western Mediterranean coast of Spain, were assessed in CIEL*a*b* 1976 colour space. The obtained results showed relevant differences between natural and artificially nourished beaches. The colour of many nourished beaches generally differs from the native one because the origin of the injected sand is different. The native sand colour coordinates' range is: $L^{*}(40.16-63.71) ; a^{*}(-1.47-6.40) ; b^{*}(7.48-18.06)$. On the contrary, for nourished beaches' the colour range is: $L^{*}(47.66-70.75) ; a^{*}(0.72-5.16) ; b^{*}(5.82-18.82)$. Impacts of beach nourishment on the native sand colour were studied at San Juan beach, the most popular one along the study area. Nourishment works were performed after severe erosion, usually linked to anthropic activities/structures and storm events, but also to increase beach width and hence benefit tourism.
\end{abstract}

Keywords: Alicante; beach nourishment; CIEL*a*b*; coastal management; Costa Blanca; mineralogical characterization; sediment colour; tourism; western Mediterranean

\section{Introduction}

Coastal sedimentological studies allow the understanding of both natural processes and anthropogenic interventions, e.g., coastal dynamics and required management actions. Beach sediments characteristics play an essential role in coastal ecology but also in the choice of a pleasant site by beach users [1]. The most important characteristics of the sediment are texture (grain size and sorting), mineralogy, colour and morphology of grains (roundness and sphericity). These characteristics should be preserved during anthropogenic actions since their modifications can cause undesired impacts. First, sediment colour and texture directly influence the perception of beach users [2] and coastal scenery characteristics [3]: beach sediment colour is one out of the 18 natural parameters considered in the probably most commonly used landscape assessment method, i.e., the Coastal Scenic Evaluation [4]. This methodology, applied in $>1000$ coastal sites around the world [5], including the study area of this paper [6], is based on enquires that revealed that golden or white sand is better valued than dark 
sand. In this way, beach users also prefer sandy sediments to gravel or pebble ones [4]. Second, beach nourishment can cause ecological and physical impacts on the coast. For example, nourishment works can degrade different beach habitats and affect several marine species [7]. Addition of new sand volumes can involve a change in sand colour, which can modify sand temperature with consequences on biological processes of different species, e.g., the sex of marine turtles [1]. Finally, beach nourishment can also modify beach characteristics such as beach profile and/or water colour. Consequently, the modification of beach colour due to sediment injection can cause discontent between local beach users and the economic impacts to the local economy [8,9]. Sardinia (Italy) constitutes an example of this socioeconomic problem, where a court case was opened stimulated by stakeholders because a natural white beach was replaced by a black one [10]. On the contrary, nourishment works can sometimes improve the natural sand colour making the beach more attractive to tourists, this way incrementing the economic value [11].

Previous studies carried out along the study area of this paper, were focused on biological, mineral, and textural characteristics [12-17]. However, no attention was focused on the chromatic analysis of native sand and its modification after beach nourishment. Such studies on beach colour are relatively recent and they have important implications for coastal conservation and beach management. Sand colour characteristics can be used to create a catalogue of sand compatibility and improve nourishment works $[3,9,18]$. This catalogue should be useful to identify the origin of sediments, as well as to detect the occurrence and level of oil contamination, e.g., after the beach oiling in NW Spain linked to the sinking of the Prestige [19]. In Tuscany (Italy), compatibility studies in sand colour [20] have been carried out to avoid future management issues. Further, the chromatic analysis of sand in combination with the study of other sedimentological parameters such as the granulometry or mineralogical composition can be used for didactic activities or as an interesting geo-sedimentary resource to outreach geoscience among the general public [21-23].

The colour of solid objects mainly depends on three factors: the light source, the observer, and especially the characteristics of the material surface [24]. The colour of a stimulus can be assessed in the CIEL*a* ${ }^{*}$ colour space, recommended by the Commission Internationale de l'Eclairage [25] and is appropriate for sediment colour comparison [26]. On the one hand, the coordinate $\mathrm{L}^{*}$ is the Lightness component, and it ranges between 0 and 100 (from black to white, respectively). It is directly associated with the visual sensation of luminosity. On the other hand, the coordinates $\mathrm{a}^{*}$ and $\mathrm{b}^{*}$ are denominated "Chromaticity". The $\mathrm{a}^{*}$ coordinate defines the deviation of the achromatic point corresponding to Clarity, to red if $a^{*}>0$ and to green if $a^{*}<0$. Similarly, the coordinate $b^{*}$ defines the deviation to yellow if $b^{*}>0$, and to blue if $b^{*}$ is $<0$ [24]; both can theoretically shift from -200 to +200 , with values external to \pm 100 being unusual $[3,26]$. Several authors have quantified the colour of beach sand from different countries (e.g., Italy, Belgium, Cuba, Portugal, New Zealand and Japan) in the CIEL*a* ${ }^{*}$ colour space $[3,9,26-29]$.

The most important characteristics of coastal sediments are particle size distribution, mineralogy, and colour (which is generally the least studied). For this reason, the main objective of this study was to carry out the first chromatic characterization of beach sands from the south-eastern coast of Spain. Samples from natural and altered (nourished) beaches were taken in order to analyse the influence of the origin of sediments on the actual beach colour and sediment chromatic characteristics were compared with the mineralogical composition of the studied sands. Colour studies in sandy beaches are very simple to perform compared to complex mineralogical studies, so it is mandatory to advance in this type of research in order to establish other objective criteria to adequately choose borrowed sand for nourishment projects. This study is the starting point for future research on sand colour characteristics in the study area in order to establish objective criteria for designing future anthropogenic actions on the coast attempting to maintain original beach sediment characteristics.

Finally, the data shows the current colour of beach sand in different locations, which can be very interesting in applied environmental studies (e.g., in terms of the beach quality assessment, tourism or engineering activities). For instance, this study can be particularly interesting to identify the type of 
sand (natural or nourished), to nourish beaches attempting to employ natural-like sand colour, and even to detect future changes in the sand colour or the presence of contaminants.

\section{Materials and Methods}

\subsection{Study Area}

The studied area covers about 200 kilometres of coastline of the western Mediterranean (SE Spain) (Figure 1). It includes 60 beaches from San Pedro del Pinatar (Murcia Province) to Dénia (Alicante Province, Figure 1, Table 1). The studied coast has very diverse habitats: dunes in the south [30], high cliffs of the Betic Cordillera in the north coast of Alicante [31], as well as beaches located on the Nueva Tabarca Island [23]. From a geological standpoint, this coastline is divided into three different domains: the southern sector mainly belongs to the Bajo Segura basin [32,33], the northern one pertains to the Prebetic zone of the External Zones of the Betic Range [34], while the Island of Tabarca is related to the Internal Zones of the Betic Range [35]. The different geological contexts in which the beaches are included establish broadly three different source areas of sediments, which constitute an intrinsic factor that determines natural sand composition and hence the native beach colour.

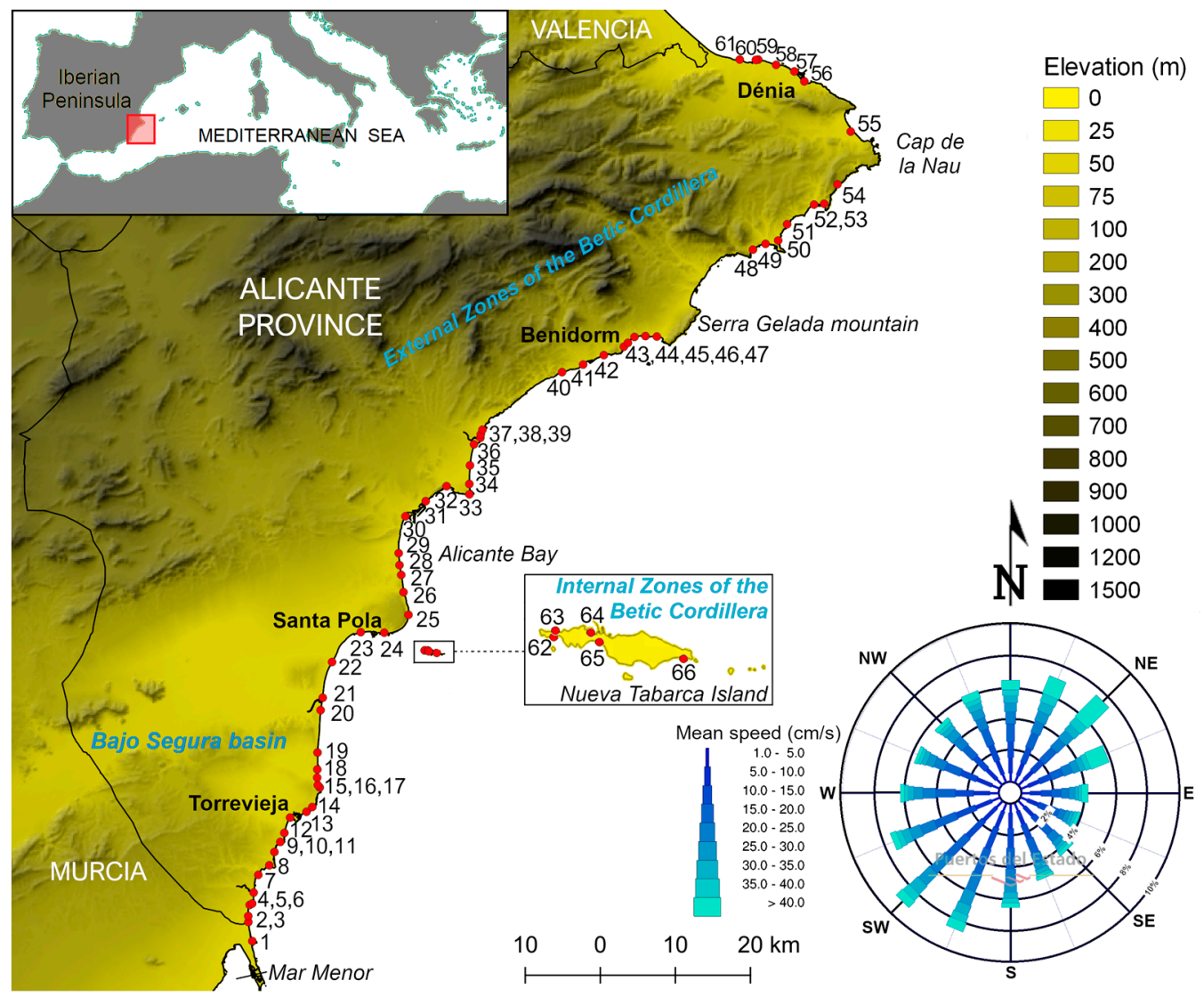

Figure 1. Location map showing the position of the 66 studied samples. Detailed information according to site numbering is showed in Table 1. Currents in Alicante area, observation period: 2006-2020 (source: www.puertos.es, accessed in January 2020).

Different natural elements reinforce the tourist attraction of the studied coastal scenery, such as cliffs, rocky shores, golden sand, dunes, turquoise water colour, and other coastal landscape features such as islands, lagoons, caves, rock ridges, and irregular headlands. However, most of the studied sites have been affected by infrastructures such as groins, seawalls, houses/buildings, parking, and nourishment works among others. Such human actuations/structures are mostly linked to the tourism 
demand and strong urban growth in the area and they have been especially frequent during recent years [36]. These anthropic structures were recently observed [6] and took into consideration 26 parameters-18 physical and 8 human-that delineate coastal scenery, according to Coastal Scenic Evaluation (CSE) Methodology [4,37], applied in different countries [5,8,38,39]. This semi-objective method utilizes weighting parameters and fuzzy logic mathematics to obtain the scenery Decision Value parameter $(D)$. This value allows the coastal areas to be classified into 5 classes, from Class I (extremely attractive/natural sites) to Class V (very unattractive/urbanized sites).

Table 1. Location and main characteristics of studied beaches: Map number (Figure 1), beach name, municipality, beach typology and sand condition with their information source.

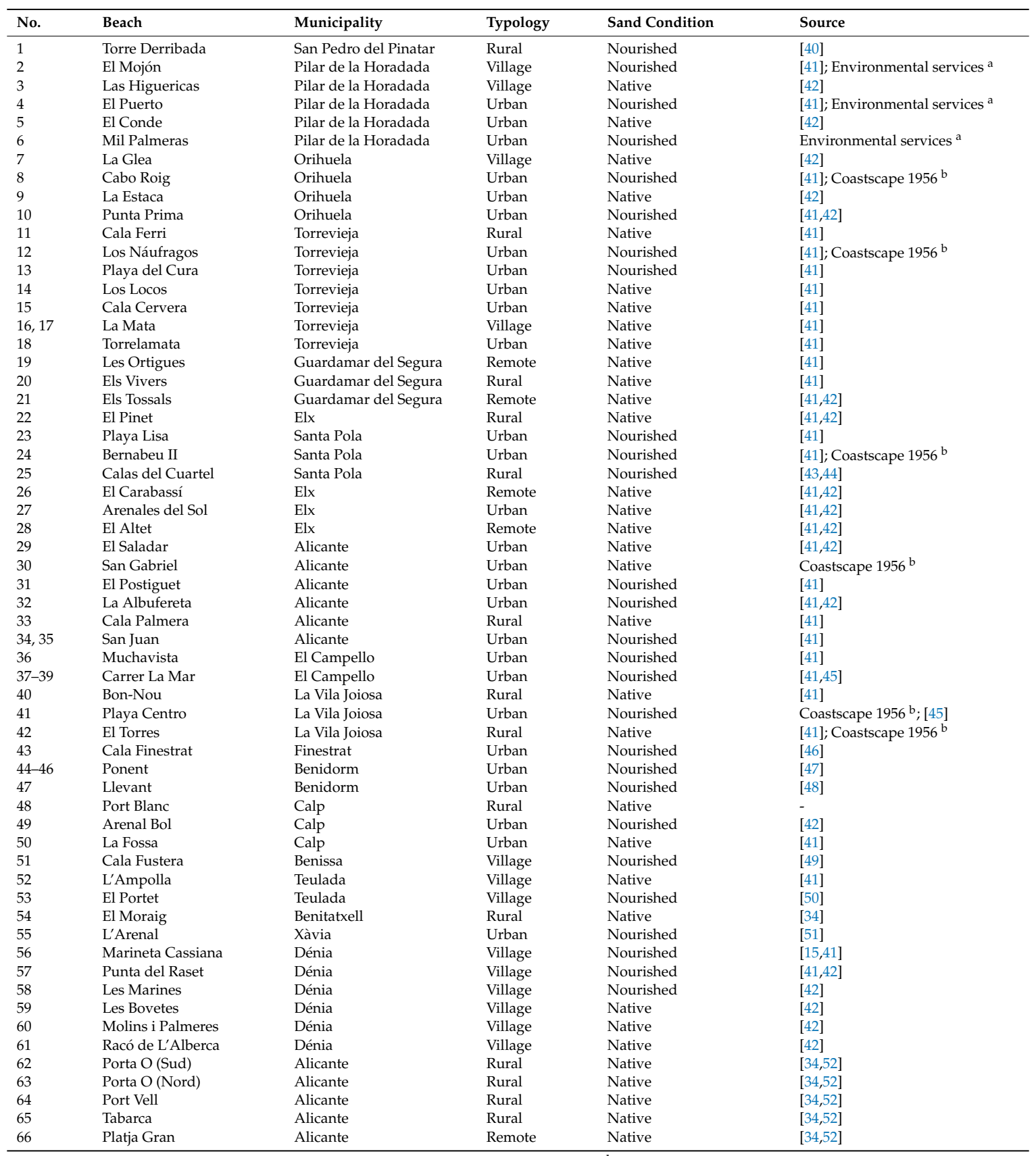

${ }^{a}$ Environmental services of the municipality (Pilar de la Horadada); ${ }^{b}$ Coastscape 1956: Comparison among images of the American Flight, B (1956-1957 years.) and current images. 


\subsection{Sampling Design}

A total of 66 sand samples were gathered in 16-19 February 2019, at sixty Mediterranean beaches (Table 1). Each sample was collected in the middle of the backshore (i.e., in the dry beach) and contained approximately $300 \mathrm{~g}$ of sand. First, the surface sand was removed and then, the sample was gathered in the first $20 \mathrm{~cm}$ of depth. On the longest beaches such as "La Mata", "San Juan", "Carrer la Mar", and "Ponent", several samples (2-3) were collected (Table 1). In this paper, only sandy beaches were investigated. For this reason, the north-eastern region has some coastal sectors not sampled due to the presence of cliffs or beaches mainly composed of gravel and boulders (Figure 1). Complementary information about the existence of anthropic actions on the sampled beaches was collected from both press news and coastal management actions by involved municipalities (Table 1).

\subsection{Sand Colour Measurement and Analysis}

The colour of sand samples was determined in the laboratory of the University of Florence (Italy) using the CIEL*a* $b^{*} 1976$ colour space [25]. It required about $100 \mathrm{~g}$ of sand per sample to measure the colour. Moreover, mineralogical composition was quantified under a binocular microscope (Nikon SMZ 1500, Nikon Corp., Japan) from the Earth Sciences laboratory of the Alicante University (Spain). For this analysis a representative sample (about 200 sand grains) was analysed and classified taking into account three main groups of components: quartz, (i.e., leucocratic component), rock fragments, and shell fragments (i.e., melanocratic components), then the values were recalculated to $100 \%$ in order to synthesize and examine the results.

Principal Component Analysis (PCA) was carried out in order to establish multivariate relationships between samples as well as connections among them considering the CIEL $\mathrm{a}^{*} \mathrm{~b}^{*}$ coordinates as input data.

Equations (1)-(3) were applied to quantify the chromatic change in a representative nourished beach (sample No. 35 , Table 1). For this, a native sample was required and measured in the CIEL*a*b* colour space with the rest of the 66 samples.

$$
\begin{gathered}
\text { Hue }(h)=\arctan \left(b^{*} / a^{*}\right) \\
\text { Chroma }\left(C^{*}\right)=\left(a^{* 2}+b^{* 2}\right)^{1 / 2}
\end{gathered}
$$

The distance between colours is given by the Euclidean distance:

$$
\Delta \mathrm{E}^{*} \mathrm{ab}=\left[\left(\Delta \mathrm{L}^{*}\right)^{2}+\left(\Delta \mathrm{a}^{*}\right)^{2}+\left(\Delta \mathrm{b}^{*}\right)^{2}\right]^{1 / 2}
$$

Sedimentological analysis (particle size distribution) was performed via dry sieving at 1 phi interval in order to have a more detailed database. For this characterization, initially, each sample contained $200 \mathrm{~g}$ of sand. The software used for data analysis was "Gradistat" [53] and granulometric parameters were calculated according to Folk and Ward (1957) [54].

\section{Results and Discussion}

\subsection{Typology of Beaches}

Table 1 shows the main beaches under study, and their typology according to the Bathing Area Registration and Evaluation (BARE) classification system [55]. This classification is based on the level of urbanization, accessibility, etc., and establishes four basic types: remote, rural, village, and urban. Remote areas are mainly defined by difficulty of access. They may be adjacent to rural areas and, occasionally, village environments. Usually, remote beaches are not supported by public transport and have very limited (0-5) or no temporary summer housing [55]. Rural areas are located outside the urbanized environment. They are not accessible by public transport and present virtually no facilities. Housing is limited in number, generally ranging from 0 to 10 . Rural beaches do not have 
permanent community focal centres (e.g., schools, shops, cafes and bars) and they have little or no beachfront development [55]. Village areas are located outside the focal urban environment and related to a small and permanent population. Village beaches may be reached by public or private transport [55]. Urban areas have large populations with well-established public services and a wellmarked central business district. In the proximity of urban areas can be found commercial activities such as fishing/boating harbours and marinas. Urban beaches are located within or adjacent to the urban area and are generally freely open to the public [55].

The selected study case is an excellent example of coastal development under high touristic pressure, with many coastal sites showing very urbanized conditions (34 studied beaches classified as Urban in Table 2) and the rest of the cases are located in urbanized environments (13 Village beaches) or they show the presence of houses (14 Rural beaches). Only a very few coastal sites (5) can be classified as natural beaches, i.e., beaches with few anthropic interventions. They were classified as Remote.

Table 2. Sector analysis approach (Sand condition and beach typology). Consider that the Chi-square Test was performed to see the level of significance among them.

\begin{tabular}{llllll}
\hline & Remote & Rural & Village & Urban & Total \\
\hline Nourished & 0 & 2 & 6 & 24 & 32 \\
Native & 5 & 12 & 7 & 10 & 34 \\
Total & 5 & 14 & 13 & 34 & 66 \\
\hline
\end{tabular}

Chi-square Test: $\alpha=0.05 ; \mathrm{df}=3 ; \mathrm{X}^{2}=17.94 ; \mathrm{p}$-value $=0.00045 ; \mathrm{X}_{3,0.05}=7.814 ; \mathrm{sig}=$ yes.

As a consequence of the urban and touristic pressure that affects the study area, some beaches have been modified by anthropogenic activities, but others have preserved their original state, i.e., only receive sand through natural processes. For this reason, a new classification was made according to sand condition: "Nourished" and "Native" (Table 1).

Nourished beaches are common in the study area [41,49-51,56-58], causing anthropogenic modifications in the original appearance of the coast [59]. Construction of dams on land that retain sediments, massive construction of buildings near the coast, creating new harbours and breakwaters, beach nourishment, as well as sand movements from beach to beach are some examples. These coastal modifications that have been carried out since approximately the middle of the 20th century [60], have changed the native sand colour among other sediment characteristics. Figures A1-A5 show the current state (February 2019) of the sampled sites. Sand colour observed in these images is a result of multiple factors acting simultaneously: the camera used, hour, luminosity of the moment (e.g., sunny or shaded), beach surface characteristics, etc. All these extrinsic determinants modify the perception of the real intrinsic sand colour, which is mainly a consequence of the mineralogical composition. For these reasons it is necessary to apply an objective methodology to quantify the chromatic appearance of samples, i.e., in a laboratory with a quasi-uniform colour space method $\left(\mathrm{CIEL}^{*} \mathrm{a}^{*} \mathrm{~b}^{*}\right)$.

\subsection{Sand Colour Analysis}

An interesting diversity of colours emerged along the study area (Figure 2, Table A1) mainly due to two factors: the different origin of sediments (intrinsic factor) and the anthropic modifications that have been carried out since approximately the middle of the 20th century (extrinsic factor). 


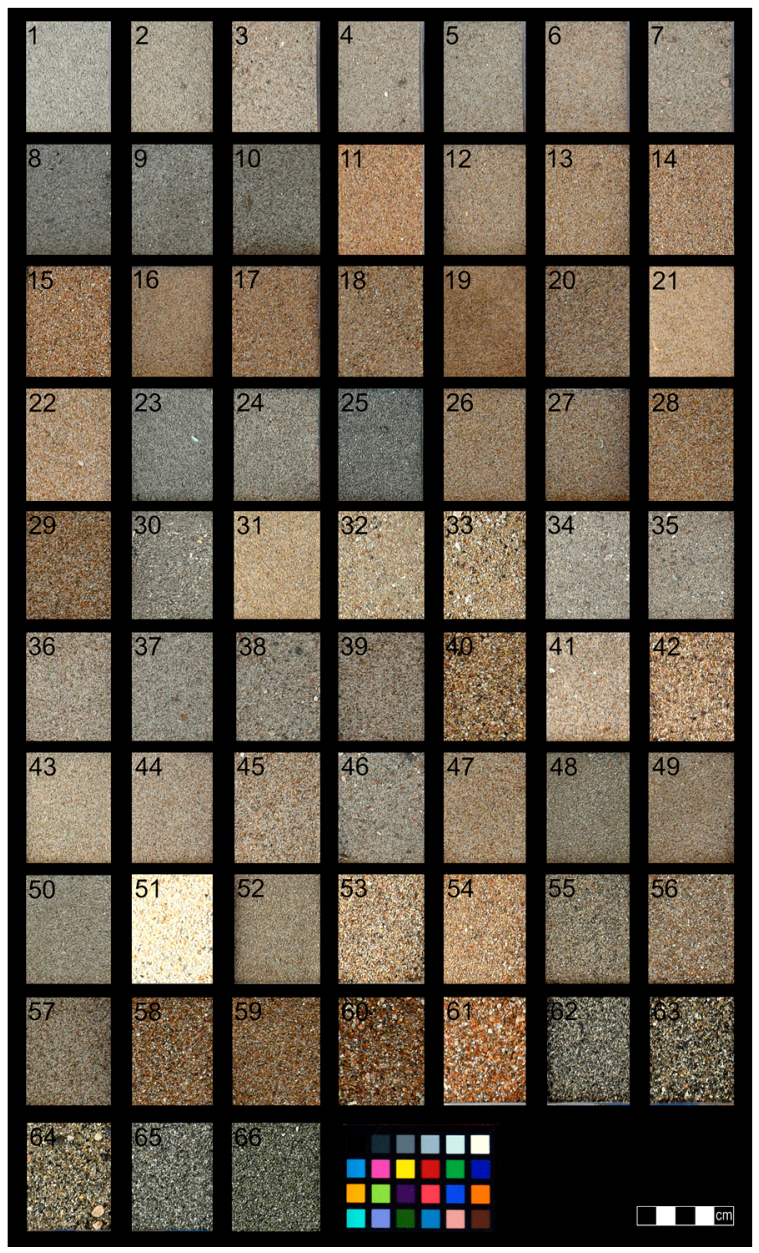

Figure 2. Sand samples from the 66 coastal sites. One shoot in sunlight including $X$-rite colour table and centimetric scale.

Regarding the colour parameters (the $\mathrm{L}^{*}, \mathrm{a}^{*}$ and $\mathrm{b}^{*}$ values) expressed in Figure $3 \mathrm{a}, \mathrm{b}$, the following considerations can be argued:

\subsubsection{The $L^{*}$ Value}

Four groups are differentiated according to the measured Lightness value: (i) samples with $L^{*}>60$ (seven samples); (ii) samples with intermediate values $\left(50<L^{*}<60\right.$ ); (iii) samples with $L^{*} \approx 48$ (four samples); and (iv) samples with $\mathrm{L}^{*}<46$ (five samples) (Figure $3 a$ ).

These results highlight the relevant underlying influence of the geological context on the final appearance of the coastal deposit. This geological frame defines the natural source area of beach grains. In this sense, the above first group includes the southern beaches. Their geological context is mainly related to the Bajo Segura basin. This source area is mostly constituted of Neogene-Quaternary sediments mainly related to continental and coastal deposits [61]. Also, this area is characterized by unaltered coastal stretches. The northern beaches related to the External Zones of the Betic range are grouped in the second group. They are the most modified beaches and only a few of them are natural (Figure 3a). The dark colour of the northernmost beaches (included in the third group) is related to the contributions of different rivers and streams (e.g., Girona River and "Barranc de L'Alberca"). However, the darkest sands correspond to those included in the fourth group. These samples are included in the geological context of the Tabarca Island (Figure 3a). In this island the outcrops are mainly materials from Internal Zones of the Betic range. The low Lightness of these natural beaches is justified by the 
high content of dark rock fragments that comes from the black dolomites and diabases, which outcrop along the island [23,52].

Two samples differ significantly from the general trend defined above. On the one hand, sample No. 62 differs from the rest of the samples located in Tabarca Island due to the influence of the yellowish calcarenites (Miocene age) that outcrop at this point of the island [23,34]. On the other hand, sample number 51 shows the highest Lightness value (i.e., 70.75, Table 3, Figure 3a) because this sand is from an inland quarry.

\subsubsection{The $a^{*}$ and ${ }^{*} b$ Plane}

The parameters $\mathrm{a}^{*}$ and $\mathrm{b}^{*}$ (Table A1) are positively correlated among them $\left(\mathrm{R}^{2}=0.89\right.$; $\mathrm{p}$-value $<0.05$; Figure $3 b$ and Table A2). The found values were more uniform than the Lightness ones. On the one hand, the parameter $\mathrm{a}^{*}$ ranges from -1.47 (sample No. 66, Platja Gran) to 6.4 (sample No. 61, Racó de L'Alberca; Figures 2 and A5). On the other hand, parameter $b^{*}$ varies from 5.82 (sample No. 25, Calas del Cuartel; Figures 2 and A2) to 18.82 (sample No. 51, Fustera Beach; Figures 2 and A4). Those samples with negative $a^{*}$ and low $b^{*}$ values have a characteristic green colour and are from the eastern side of Tabarca Island where the beaches are dominated by metagabbro clasts proceeding from eroded cliffs [23]. On the opposite side, several native samples (No. 11, 14, 15, 17, 19, 28, 40, 54, 59, 60,61 , Table 1) stand out, with their values towards the yellow-red colour (Figure 2) resulting in an attractive golden sand.

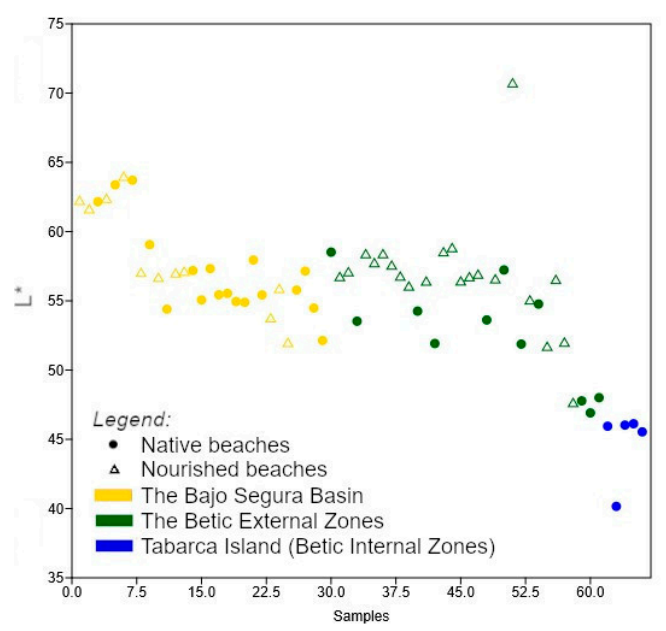

(a)

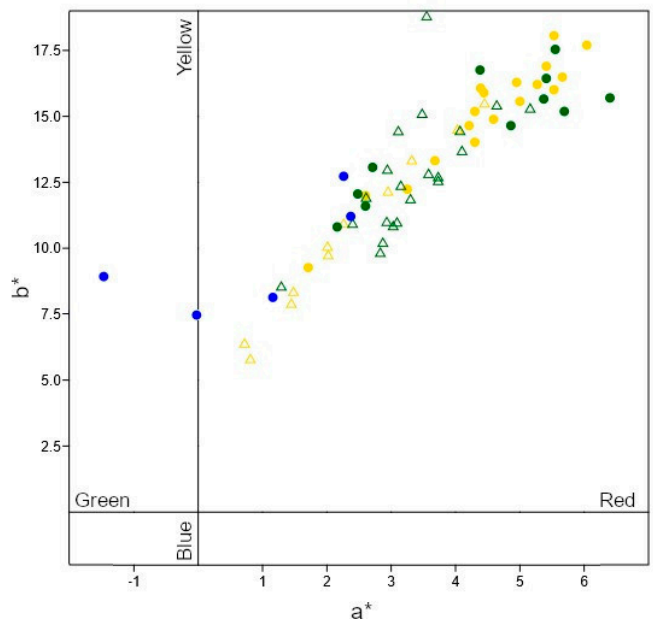

(b)

Figure 3. (a) The Lightness $\left(\mathrm{L}^{*}\right)$ from sample number 1 to sample number 66 , the beaches of Tabarca Island were enumerated, the last ones from west to east (Figure 1 and Table A1). (b) Sample position in the $a^{*}, b^{*}$ plane (CIEL ${ }^{*}{ }^{*} b^{*}$ colour space; illuminant D65, Table A1). Colour (yellow, green and blue) refers to the geological domains of the study area (respectively, The Bajo Segura basin, The Betic External Zones, and the Tabarca Island which belongs to the Betic Internal Zones).

\subsection{Mineralogical Characterization}

Mineralogical composition of the studied sands is very diverse, showing variations in the type of minerals and also in the relative proportion in which they are represented. The colour of each grain is directly related to its mineralogical composition and, therefore, the global colour of the deposit is the result of the presence of certain grains and their abundance.

Leucocratic components (mainly transparent grains with angular morphology) were identified, and they correspond mainly to quartz $\left(\mathrm{SiO}_{2}\right)$. They are very well represented in all samples in variable proportions (from $8.08 \%$ to $72.26 \%$, Table 3 ). Melanocratic components correspond mainly to both rock fragments (basically calcarenites and dark carbonate rocks) and other minerals such as pyroxenes, amphiboles, and biotites. In general terms, melanocratic components are more abundant 
than leucocratic ones, especially at Tabarca Island (Figure 4). Their abundance varies along the study area from $27.74 \%$ to $91.92 \%$ (Table 3). Finally, bioclasts (i.e., small fragments of shells, sea urchins, calcareous algae, corals, etc.) were also counted and their proportion in the study area is very low, almost insignificant. Due to the dark aspect of bioclasts and their low abundance, they were included in the melanocratic fraction.

Concerning the abundance of leucocratic and melanocratic components, 14 samples contained less than $50 \%$ of leucocratic components, while the rest (52) contained $\geq 50 \%$ of melanocratic components (Figure 4). Table 3 shows median, mean, as well as minimum and maximum values of the colour data $\left(\right.$ CIEL $\left.^{*} \mathrm{a}^{*} \mathrm{~b}^{*}\right)$ and mineralogical composition, i.e., percentage of leucocratic and melanocratic components.

Table 3. Summary of colour and mineralogical parameters.

\begin{tabular}{cccccc}
\hline & $\mathbf{L}^{*}$ & $\mathbf{a}^{*}$ & $\mathbf{b}^{*}$ & Leucocratic Components & Melanocratic Components \\
\hline Min. & 40.16 & -1.470 & 5.82 & 8.08 & 27.74 \\
Median & 56.44 & 3.400 & 13.04 & 39.30 & 60.70 \\
Mean & 55.48 & 3.452 & 13.04 & 38.23 & 61.77 \\
Max. & 70.75 & 6.400 & 18.82 & 72.26 & 91.92 \\
\hline
\end{tabular}

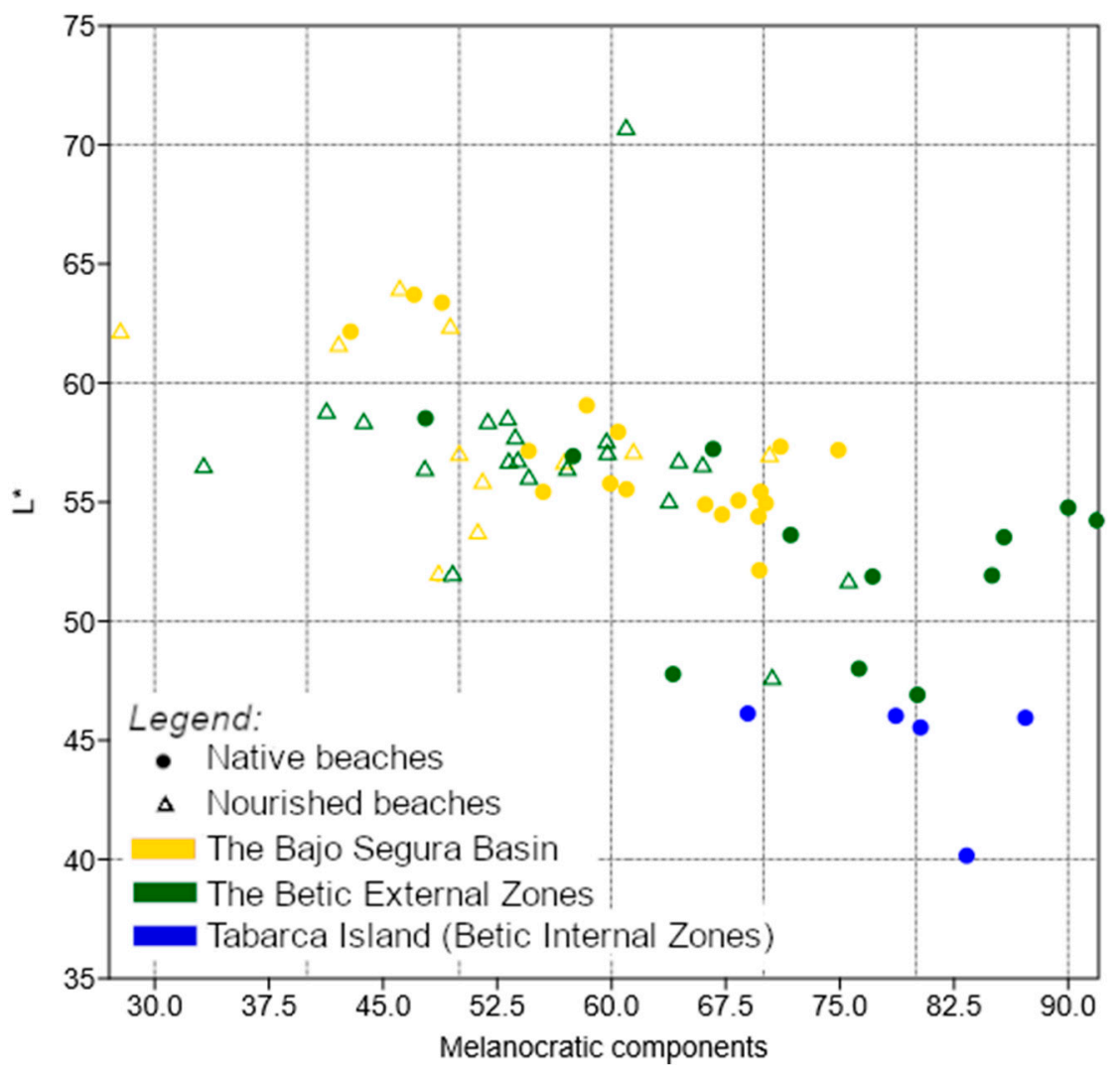

Figure 4. Sample position according to the Lightness $\left(\mathrm{L}^{*}\right)$ and percentage of melanocratic components. Colour (yellow, green, and blue) indicates the geological domains to which the studied beaches belong (respectively, The Bajo Segura basin, The Betic External Zones, and the Tabarca Island which belongs to the Betic Internal Zones).

\subsection{Statistical Analysis}

In order to find correlations among the different colour and mineralogical parameters, the Pearson correlation statistic coefficient was obtained (Table A2). On the one hand, the highest correlation was found among $\mathrm{a}^{*}$ and $\mathrm{b}^{*}$ parameters $\left(\mathrm{R}^{2}=0.89 ; \mathrm{p}\right.$-value $\left.=2.2 \times 10^{-16}\right)$. On the other hand, $\mathrm{L}^{*}$ parameter shows a good correlation with the leucocratic component $\left(R^{2}=0.62\right.$; $p$-value $\left.=2.187 \times 10^{-8}\right)$. 
Quartz grains normally present light colours and their high proportion in samples determines sand clarity. In this way, the content of quartz grains is inversely proportional to the $\mathrm{a}^{*}$ and $\mathrm{b}^{*}$ colour parameters as was previously concluded for the Belgian coast [9].

Principal Component Analysis (PCA) is a multivariate-statistical technique used for reducing the dimensionality of data. The resulting analysis is shown in a two-dimensional plot composed of two axes or components, PC1 and PC2 (Figure 5). PC1 explained $63.57 \%$ of the total variance and PC2 $32.83 \%$. The cumulative proportion of the second principal component was $96.39 \%$ (the data were previously normalized). In the graph, the three colour variables $\left(\mathrm{L}^{*}, \mathrm{a}^{*}\right.$, and $\left.\mathrm{b}^{*}\right)$ are represented with arrows and each one of the 66 investigated sites is located in the graph according to its relation with the variables, a technique applied previously in another sand colour study with important implications for beach nourishment and coastal management [26]. The resulting distribution of the samples in the graph is due to both their geographical location mainly related to the geological context and anthropic actions carried out on the deposit (i.e., nourishment works). Four groups of beaches were identified in the graph of Figure 5 according to their geographical location ("neighbouring beaches"): (i) the southernmost beaches $(n=7)$; (ii) the northernmost beaches $(n=4)$; (iii) beaches of Santa Pola $(n=3)$; and (iv) beaches of Tabarca Island $(n=5)$.

Moreover, very interesting groupings can be observed according to sand condition consulted in the bibliography (Table 1). A group of natural samples $(+10)$ from different municipalities is shown towards the arrows of the colour variables ( $a^{*}$ and $b^{*}$, Figure 5). On the left side of the graph (Figure 5) there are generally those beaches identified as natural or without alterations in colour of sand. The sand composition of the northern beaches was also considered as native (Table 1) where sediment supplies mainly arrive from the river and nearby streams. The sand of Tabarca beaches is also native and its source area is the island itself and seabed. In the central sector of Figure 5 there are beaches located in the central-northern part of the study area. Some of them correspond to modified beaches by nourishment works and emplacement structures, e.g., harbours (No. 38, 39, 41, 46, 48, 53, 57).

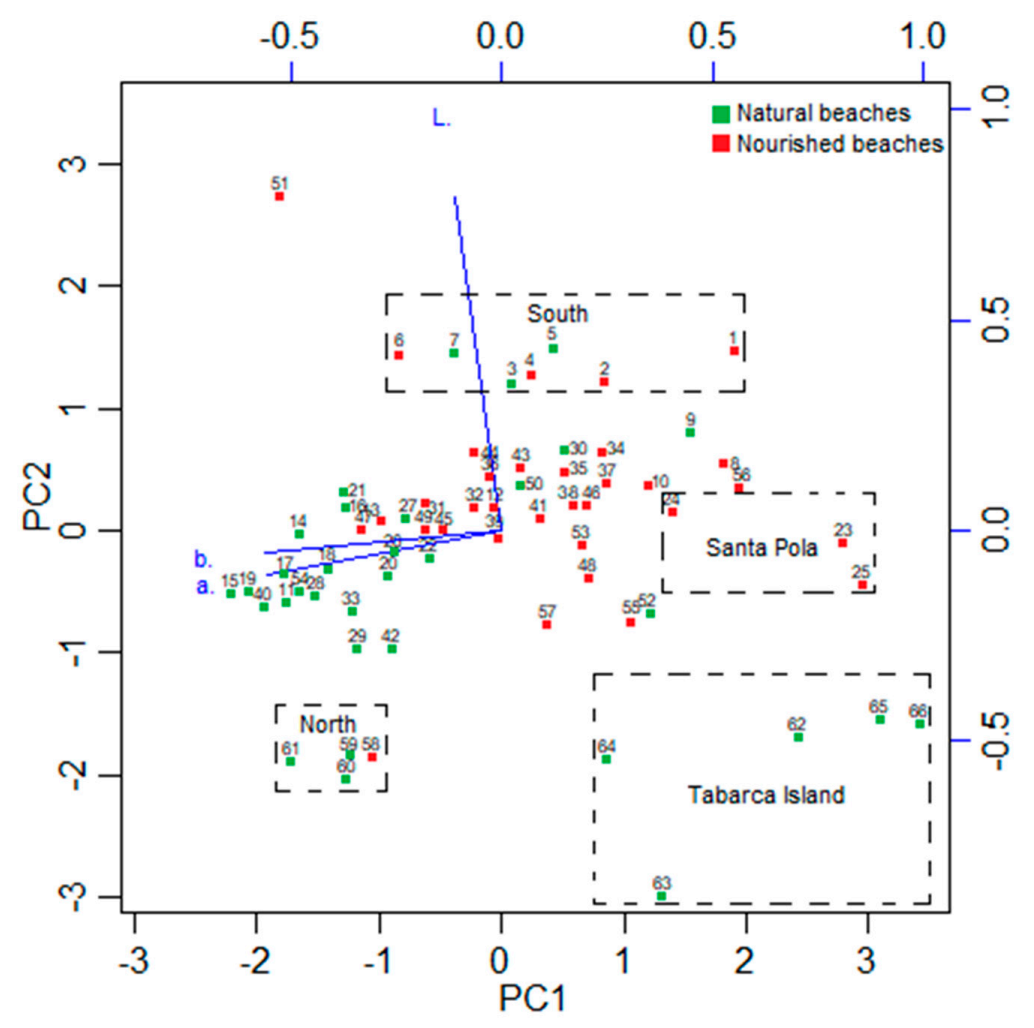

Figure 5. Principal Component Analysis (PCA) graph: representation of sand samples according to colour variables $\left(L^{*}, a^{*}\right.$, and $\left.b^{*}\right)$. See Table A1 for numerical information of each variable. Green colour: native samples; red colour: altered samples (information obtained from bibliography data, Table 1). 


\subsection{Grain Size Parameters}

The sediment studied from the 66 samples was classified mainly as coarse sand (78.8\%), very coarse sand $(12.6 \%)$, and medium sand $(6.5 \%)$. Beaches in the southernmost part of the study area were composed essentially of fine sand, while from the central part to the north, different types of beaches can be observed with rocky shores, gravel, pebbles, with fine, medium and coarse sand. Table A1 shows some of the grain size parameters of each sample.

\subsection{Colour Modification due to Human Activities}

As a consequence of the urban and touristic pressure, artificial beaches were created and deep modifications in the native coastal deposits were carried out. The sand used to nourish the beaches came from different sources: (i) submerged sandbanks (e.g., San Juan beach, No. 34-35), sometimes near to the mouth of harbours; (ii) from other beaches (e.g., El Puerto beach, No. 4); and even (iii) from a quarry inland (Fustera Beach, No. 51).

At the beginning of the 1990s one of the largest beach modifications in the province of Alicante was carried out in San Juan beach (Figure 6). Thanks to a sample of sand from the late 1980s it was possible to compare the native colour of the sand with the current one of the nourished beach, whose sand grains come from the littoral bottoms in front of the Serra Gelada Mountain (Benidorm, Alicante) [57]. Table 4 shows the colorimetric parameters of two samples from different years (1989/2019) and gathered in the same coastal sector of the beach. Difference of colour values between these two samples was estimated [62].

Table 4. Coordinates in CIEL*a*b* colour space and their differences at the San Juan beach.

\begin{tabular}{ccccccc}
\hline Sample & $\mathbf{L}^{*}$ & $\mathbf{a}^{*}$ & $\mathbf{b}^{*}$ & $\boldsymbol{\Delta} \mathbf{L}^{*}$ & $\boldsymbol{\Delta} \mathbf{a}^{*}$ & \multicolumn{1}{c}{$\mathbf{b}^{*}$} \\
\hline San Juan II (2019 year.) & 57.76 & 3.03 & 10.86 & \multirow{2}{*}{3.85} & 1.15 & 5.84 \\
San Juan (1989 year.) & 61.61 & 4.53 & 16.70 & & & \\
\hline
\end{tabular}

Equations (1) and (2) show the mathematical expression for quantifying the chromatic change in terms of Hue differences $(\Delta \mathrm{h})$ and Chroma differences $\left(\Delta C^{*}\right)$. The parameter Total Colour Difference $\left(\Delta \mathrm{E}^{*}\right.$, Equation (3)) is also used. The above calculations show that the colour of the beach after nourishment works can change even when sediments come from near submerged areas. The colour change is registered in all the chromatic parameters $\mathrm{L}^{*}, \mathrm{a}^{*}$, and $\mathrm{b}^{*}$ (Table 4$)$, and differences of $-0.4^{\circ}$ (h), $-6\left(C^{*}\right)$, and $7.15\left(\Delta \mathrm{E}^{*}\right)$ are evidenced by different equations. All these values reflect a significant aesthetical change of the coastal deposit after the nourishment. On the one hand, the negative values of $\Delta \mathrm{h}$ and $\Delta \mathrm{C}^{*}$ mean that the new appearance of the altered San Juan beach is duller and more brown than the native aspect. Therefore, the new beach colour is more distant from the ideal golden or light sand appreciated by beach users [6]. On the other hand, the high $\Delta \mathrm{E}^{*}$ value indicates that the chromatic change is clearly perceptible by local beach users, this occurs when the Total Colour Difference parameter exceeds three units $\left(\Delta \mathrm{E}^{*}>3\right)$ [63]. Another similar example is the Varadero beach (Cuba) where beach nourishment works performed several times in the past decades with nearshore sands changed the original beach colour that was the second lightest one out of 100 in Cuba, now occupying only the fiftieth position in rank [26].

San Juan beach is a clear example showing how the construction on the coast imposes a barrier to wind dynamics that can even cause the disappearance of beaches with the consequent requirement of nourishment works (Figure 6). In addition, river channelling and sediment retention in upstream reservoirs, which contribute to the erosion of beaches [64,65], have played a significant role in the reduction of the sediment input to this representative beach of south-eastern Spain. Historical bathymetric measures in reservoirs of the study area confirm this issue (Centre for Hydrographic Studies). Indeed, San Juan beach has been the subject of geological outreach activities to promote the Geoheritage of the area, which has also very didactic geological and sedimentary 
outcrops [66]. In the didactic activities undertaken [67], the sedimentological analyses of the sand (colour, sorting and presence of bioclasts) has been used to understand and reflect on the differences between the natural and the nourishment sediments of the beach, and how important it is to attempt to archive equivalent sands to the original in beach nourishment works.

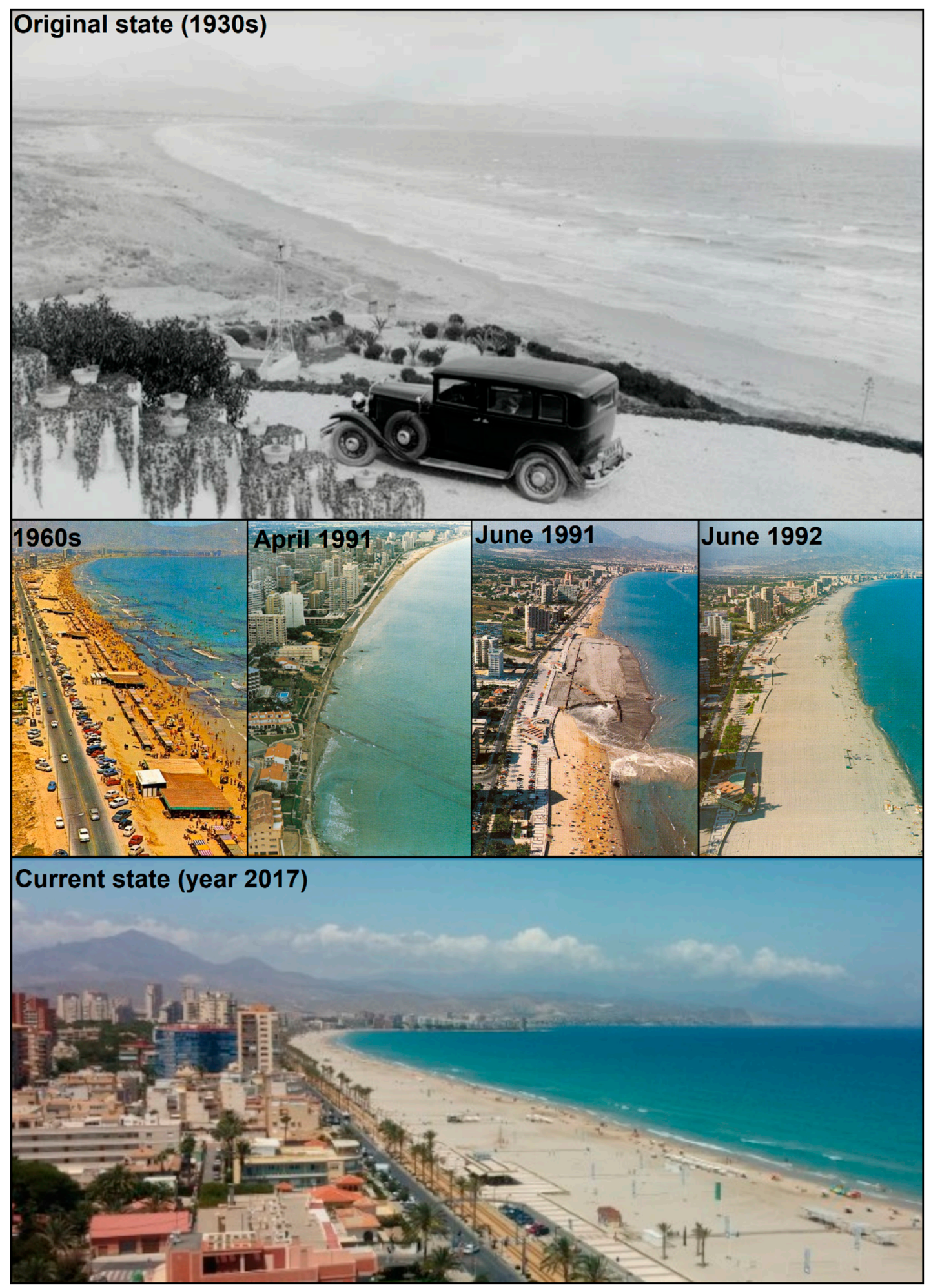

Figure 6. San Juan beach. From the original condition to the present one $[57,68-70]$. 
The study case of "Cala Fustera" (No. 51, Table A1, Figures 7 and A4) constitutes another example of significant coastal alteration after nourishment works. In this case, the previous sand deposit was replaced in 2017 by artificial quarry sand. Figure 7 shows visually differences in the colour of the coast of the Fustera Beach (now composed of quarry sand) with respect to the native colour in this coastal area, which can be seen at the Pinets beach. This original deposit is mainly composed of rocky shore with Posidonia oceanica banquettes (that are the characteristics that Fustera Beach should have). Unfortunately, no sand sample from the native Fustera Beach deposit was available. However, colour differences have been assessed assuming that the original aspect of the beach was similar to the sand colour of adjacent beaches. In this case, the chromatic change parameters take values of $\Delta \mathrm{h}=0.01$, $\Delta \mathrm{C}^{*}=8.13$ and $\Delta \mathrm{E}=20.55$, indicating that the new beach appearance is much whiter and bright than the original aspect.

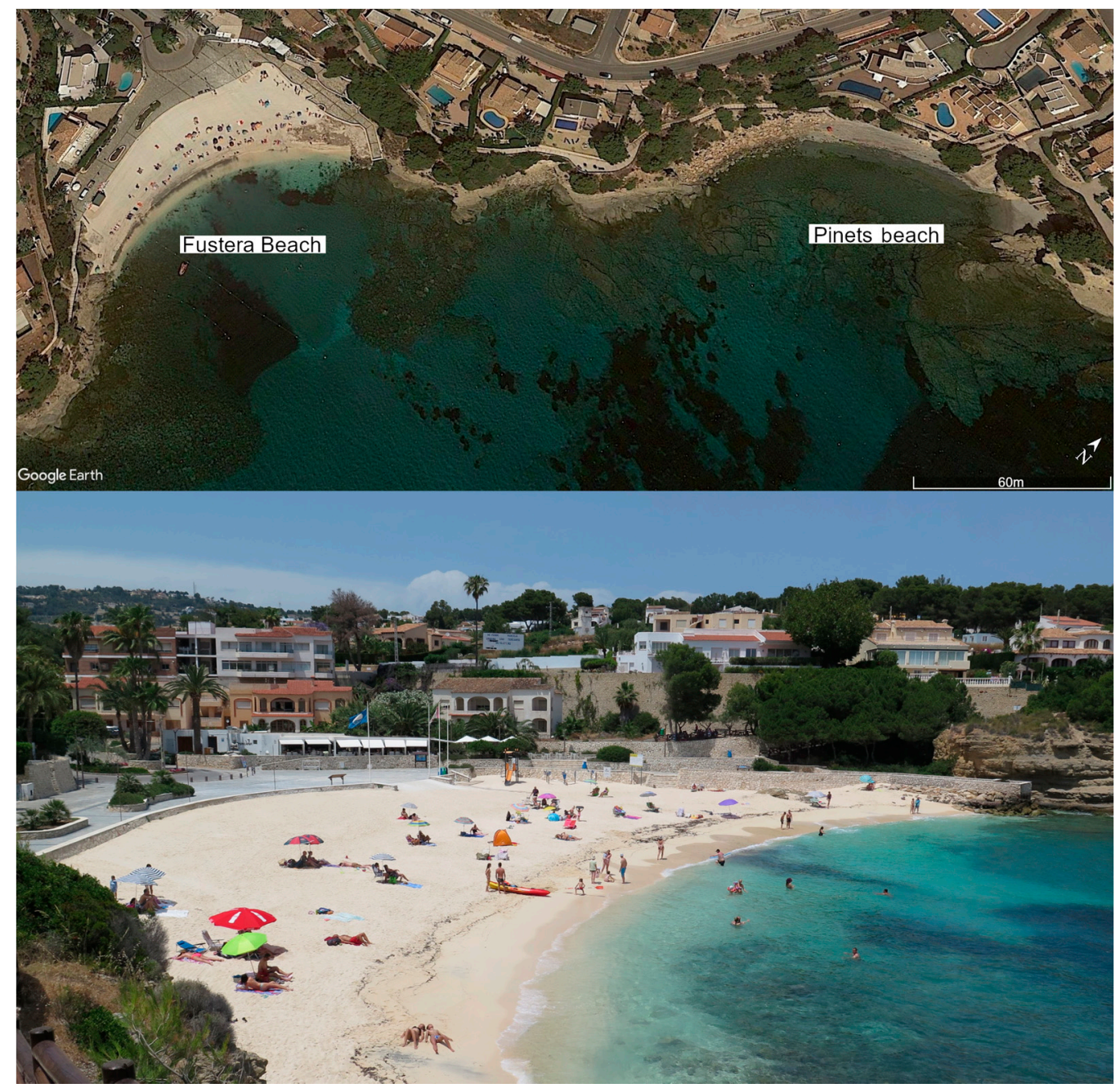

Figure 7. Fustera Beach nourished in 2017 with quarry sand (No. 51, Table A1), and Pinets beach, non-altered site. The contrast between the artificial beach vs the natural one is obvious (2018 year.). The bottom of the figure shows Fustera Beach in summer 2017.

A third example of sand colour modification due to management actions is the case of El Puerto beach (sample No. 4) located in Pilar de la Horadada, Alicante. In this case, sand from the El Puerto beach (a site next to a harbour from where sand is usually dredged, Figure 8) was transferred to other beaches such as "El Mojón" or "Mil Palmeras". Figure 8 shows the contact between the old and new coastal deposit. The colour difference of the added sand can be justified because the southern beaches are grouped at the top of Figure 5 with important differences in $a^{*}$ and $b^{*}$ parameters. 


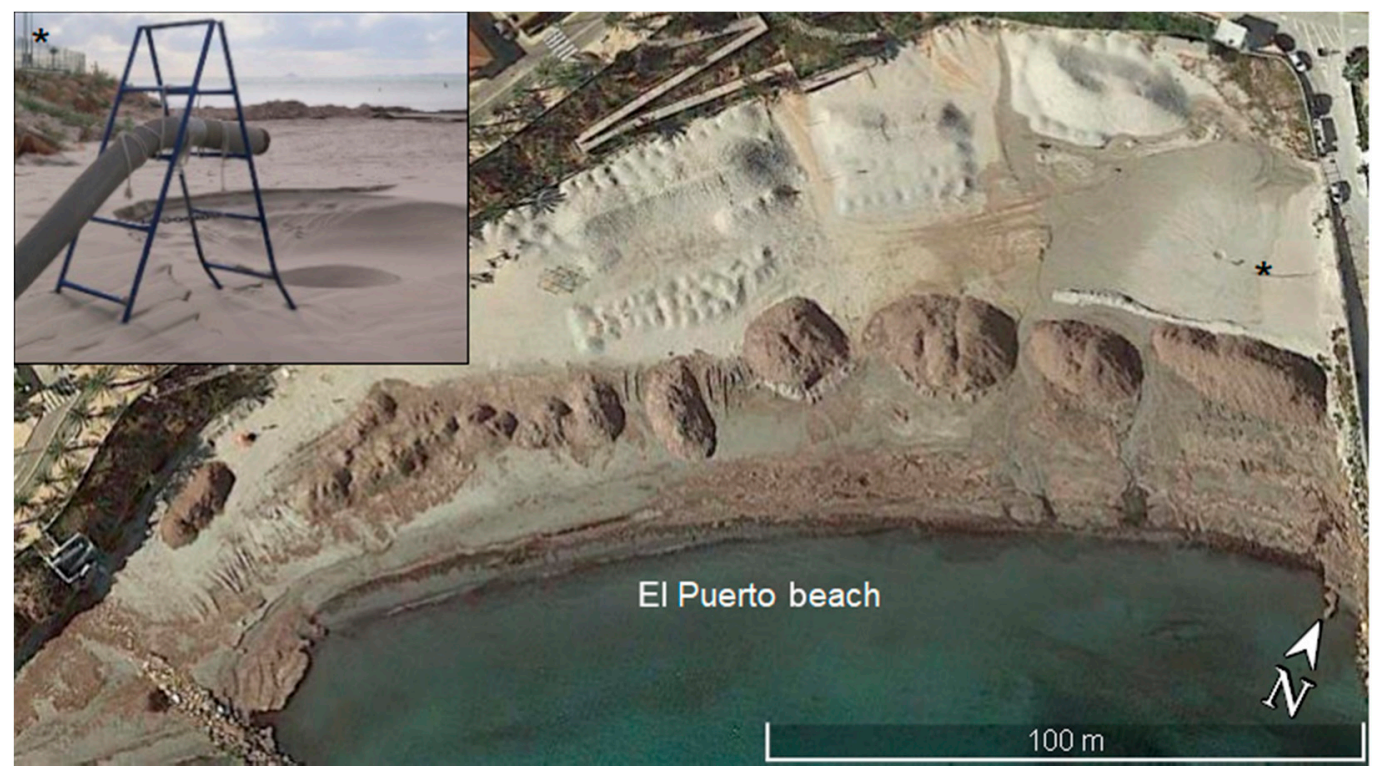

Figure 8. El Puerto beach. One of the places where sand is dredged, mixed and distributed to other beaches [71,72]. Image source: Google Earth Pro (18 March 2017).

\section{Conclusions}

This research is a new contribution to the diverse geological heritage of the southeast of the Iberian Peninsula. Sand colour of natural beaches is influenced by the geological context in which they are located: External and Internal zones of the Betic Cordillera, and the Bajo Segura basin. These three main source areas of sediments determine natural sand composition and thus, the native beach colour. Because of this, the resulting colour of each beach is the consequence of their mineralogical composition linked to the source and hydrographic basin. In this sense, natural beaches related to the geological context of the Bajo Segura basin are clearer than the rest due to the high content in quartz grains, especially the southernmost ones. On the contrary, the darkest beaches are located in Tabarca Island, whose rocky outcrops mainly belong to the Internal zones of the Betic Cordillera. Therefore, although geology is the basis of the native beach colour, human factors can modify sand characteristics, as in the case of several studied beaches, especially those related to the geological context of the External Zones of the Betic Cordillera.

To measure the colour in sandy sediments it is adequate to apply CIEL $\mathrm{a}^{*} \mathrm{~b}^{*}$ methodology to objectively quantify the chromatic appearance of each sample. In the study area, generally nourished/altered beaches differ from the native ones. The alteration of the sand colour by anthropic actions transformed the natural colour increasing green and blue tones ( $\mathrm{a}^{*}$ and $\mathrm{b}^{*}$ colour components) and Lightness (positive values in $\mathrm{L}^{*}$ ). Despite this, a big group of natural beaches was identified with the highest $\mathrm{a}^{*}$ and $\mathrm{b}^{*}$ values (towards red and yellow tones). Colour and mineralogical parameters are related among them, such as the Lightness and the content of leucocratic components. Many beaches with native sand present a high content of melanocratic components $(>60 \%)$, while most of the nourished beaches normally show less than $60 \%$ of such components. Principal Component Analysis shows good groupings associated with the mineralogical composition (related to the geographical location) and anthropic vs natural beaches. The position of the samples in the PCA graph is very useful to compare the sand colour from different beaches and also to interpret the limited information about nourishment works carried out in the past.

The 66 investigated samples differ in colour parameters and the beaches that receive more tourists have been nourished and tend to be clearer (e.g., "Ponent", "El Postiguet", "San Juan"). Results show that a few nourished beaches, e.g., "Playa del Cura", "Llevant", "Arenal Bol", "El Postiguet", and "Ponent", have a similar colour to the nearby native ones. The rest of the nourished beaches have lower 
values of $\mathrm{a}^{*}$ and $\mathrm{b}^{*}$ colour parameters, moving towards green and blue tones, e.g., "Punta Prima", "Marineta Cassiana", "Playa Lisa", "Bernabeu II", "Calas del Cuartel”, etc. Despite this, native clear samples generally presented higher values in the $\mathrm{a}^{*}$ and $\mathrm{b}^{*}$ parameters, this giving a more golden visual appearance, e.g., Ferri Beach, Cervera Beach, "Los Locos", "Les Ortigues", "La Mata" or "Bon-nou" among others. Today, the beach colour is not taken into consideration in some nourishment works, at least in the study area where "El Puerto" in the south or Fustera Beach in the north are clear examples.

This study showed with analytical data a post-nourishment change in sand colour, a common consequence also produced in other coastal sites such as Italy, Belgium or Cuba. Such changes may not be appreciated by national and international tourists as well as by old local beachgoers. The CIEL*a*b* colour space used to characterise sediment colour and Lightness is a useful tool to avoid significant changes in sand colour that can affect coastal scenery, beachgoers preferences, and the biological processes of some species. Native sediment colour is a natural characteristic of the coastal landscape and for this reason it should be maintained, at least in rural beaches and natural parks. It is essential to preserve the most natural coastal areas such as the dunes of Guardamar or the Island of Nueva Tabarca, considered by the Spanish Geological Survey as places of geological interest, mainly due to their geomorphological, sedimentological and stratigraphic particularities. In urban beaches, where all is artificial, a change of sand colour can be accepted in order to improve the beach attractiveness. Regarding future research prospects on the colour of beach sand, it would be interesting to analyse the sand properties against time in order to detect possible changes in the coastal environment.

Sand is a limited and increasingly valuable resource. Its use and relocation generates strong environmental, economic, and social impacts, especially on the coast. For this reason, it is preferable to opt for dune restoration and the elimination of unnecessary structures/constructions (on the coast or inland) that promote beach erosion instead of proposing nourishment projects that involve large economic investments and that may affect different coastal and marine habitats as well as associated species. Finally, the method used in this paper is easy to apply and can be very useful to carry out appropriate erosion management actions by means of beach nourishment works in the future. Consequently, the current conclusions are of particular interest to future actions to preserve the natural environments and original characteristics of native deposits.

Author Contributions: Conceptualization, F.A.-M. and H.C.; methodology, E.P., I.C. and H.C.; software, F.A.-M.; formal analysis, E.P.; investigation, F.A.-M. and H.C.; resources, E.P.; data curation, F.A.-M.; writing-original draft, F.A.-M., J.M.-M. and H.C.; writing-review and editing, E.P. and G.A.; visualization, J.M.-M.; supervision, H.C.; funding acquisition, H.C. and G.A. All authors have read and agreed to the published version of the manuscript.

Funding: This research received no external funding.

Acknowledgments: Special thanks go to Laura Piqueras for her technical support in the laboratory. The authors would also like to thank Jesús Soria for providing us with a 30-year-old sand sample (native) from San Juan beach.

Conflicts of Interest: The authors declare no conflict of interest.

\section{Appendix A}

As complementary material, photographs of each of 66 sampling points (Figures A1-A5) and other relevant numerical data (Tables A1 and A2) are attached. 


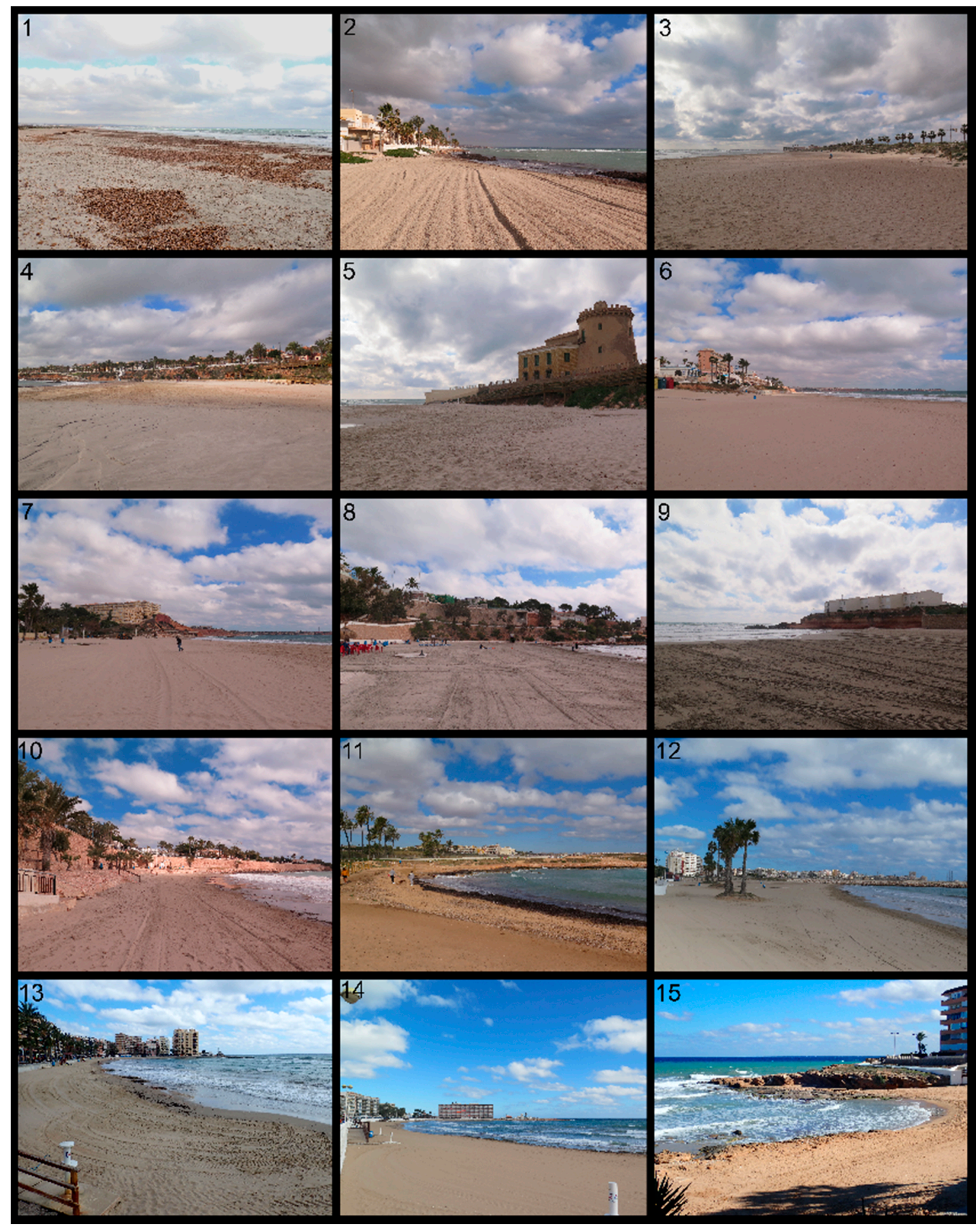

Figure A1. Beaches investigated: from “Torre Derribada" (No. 1) to "Cala Cervera" (No.15). 


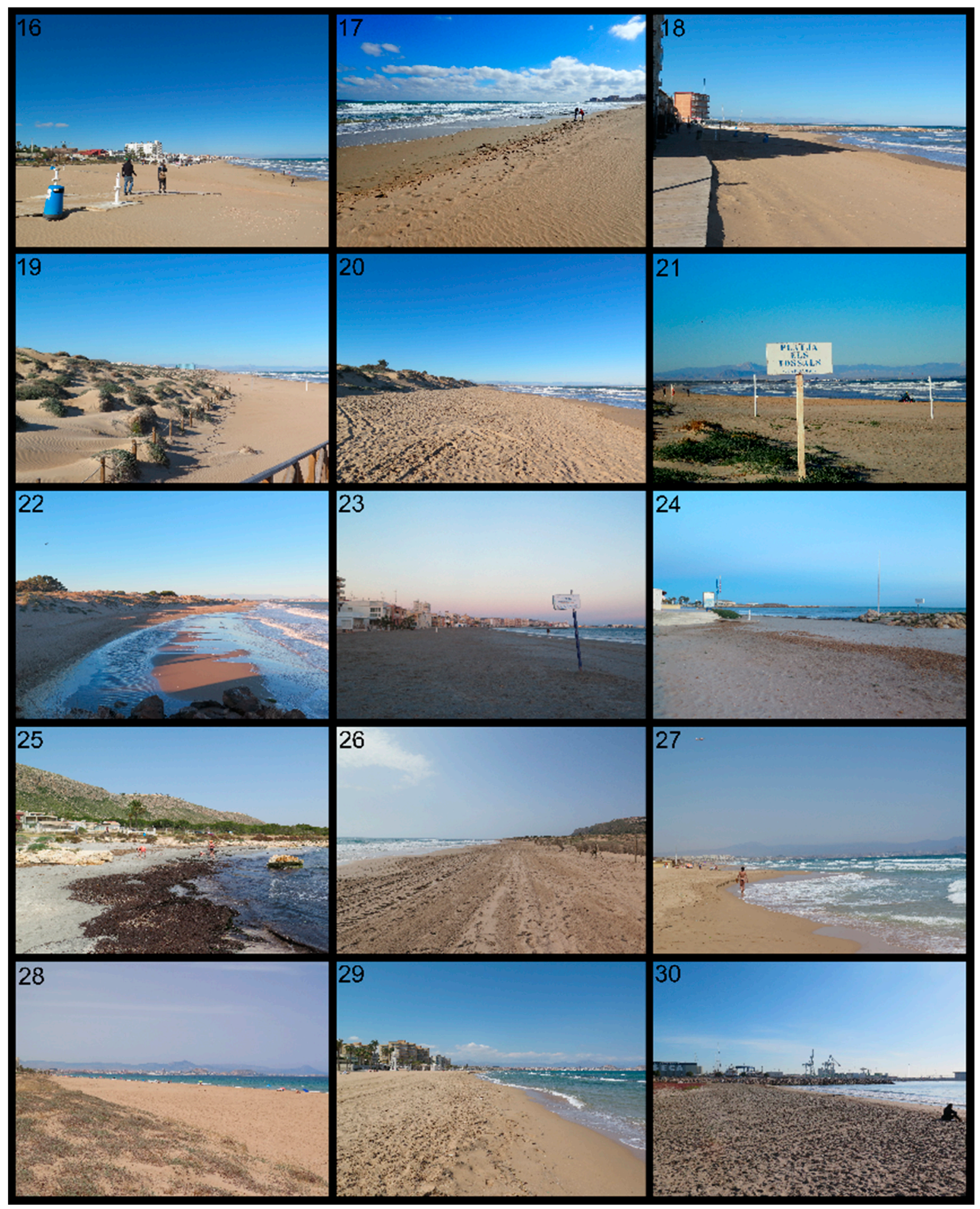

Figure A2. Beaches investigated: from “La Mata I" (No. 16) to "San Gabriel” (No.30). 


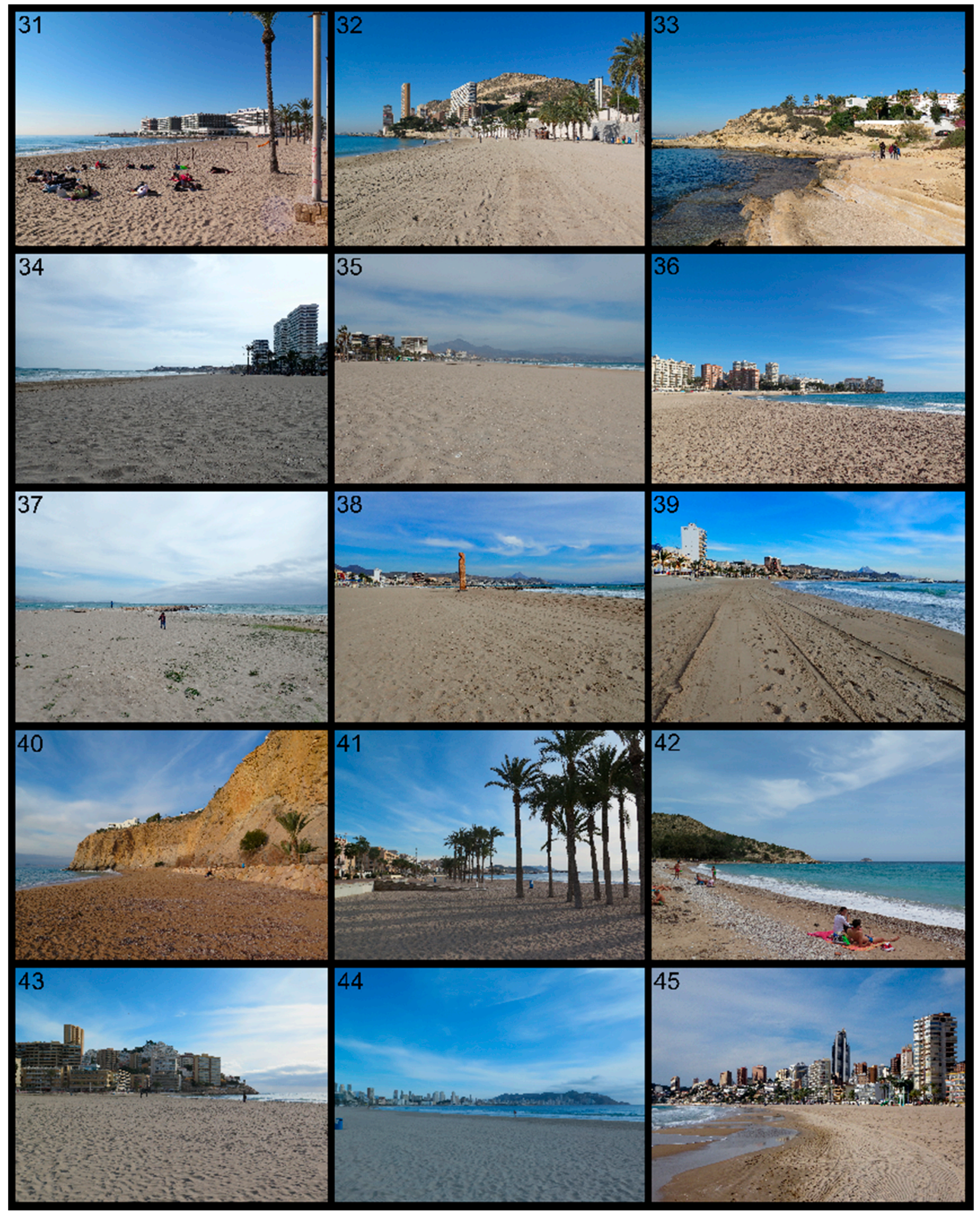

Figure A3. Beaches investigated: from “El Postiguet" (No. 31) to "Ponent II" (No.45). 


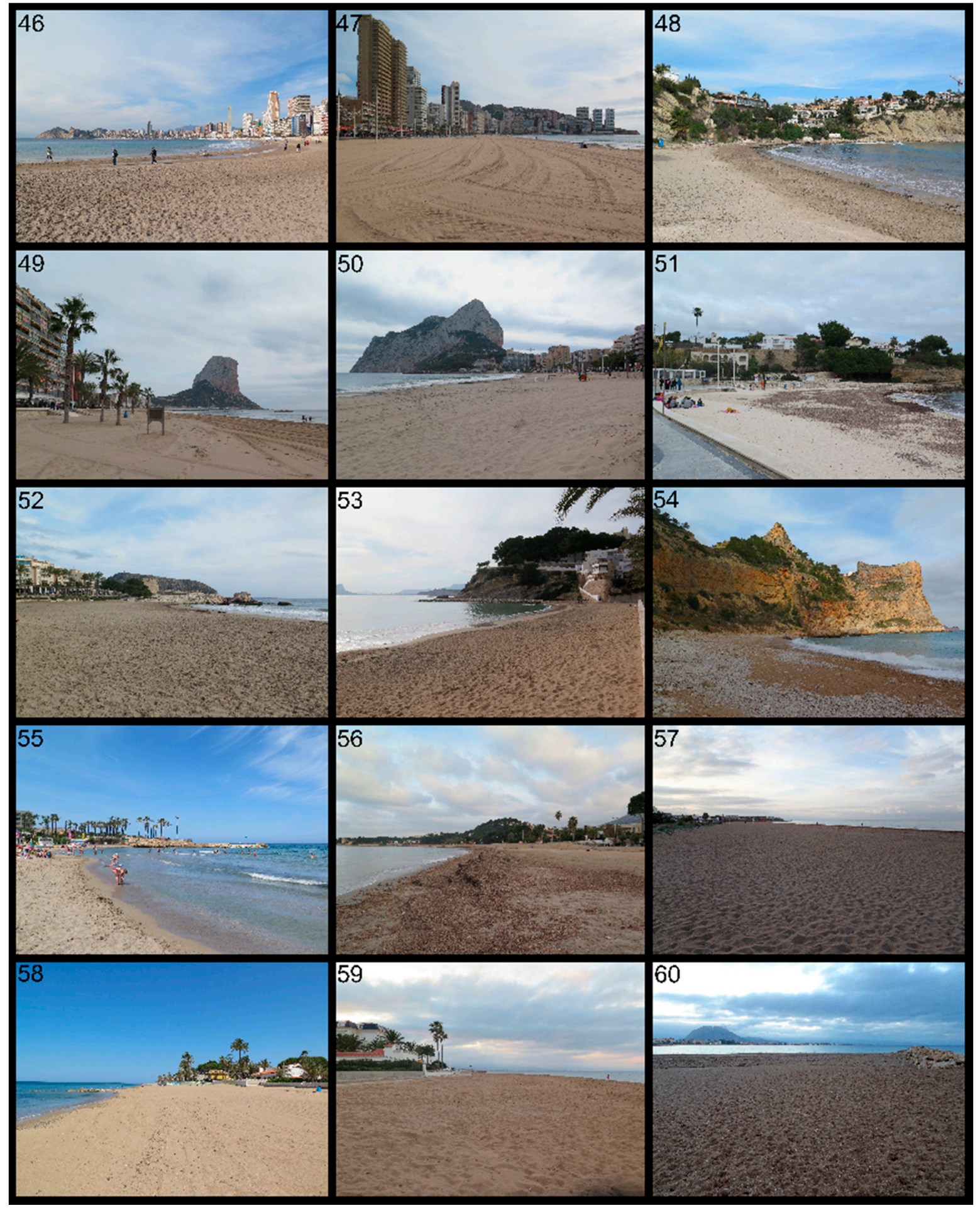

Figure A4. Beaches investigated: from “Ponent III" (No. 46) to “Molins i Palmeres" (No.60). 


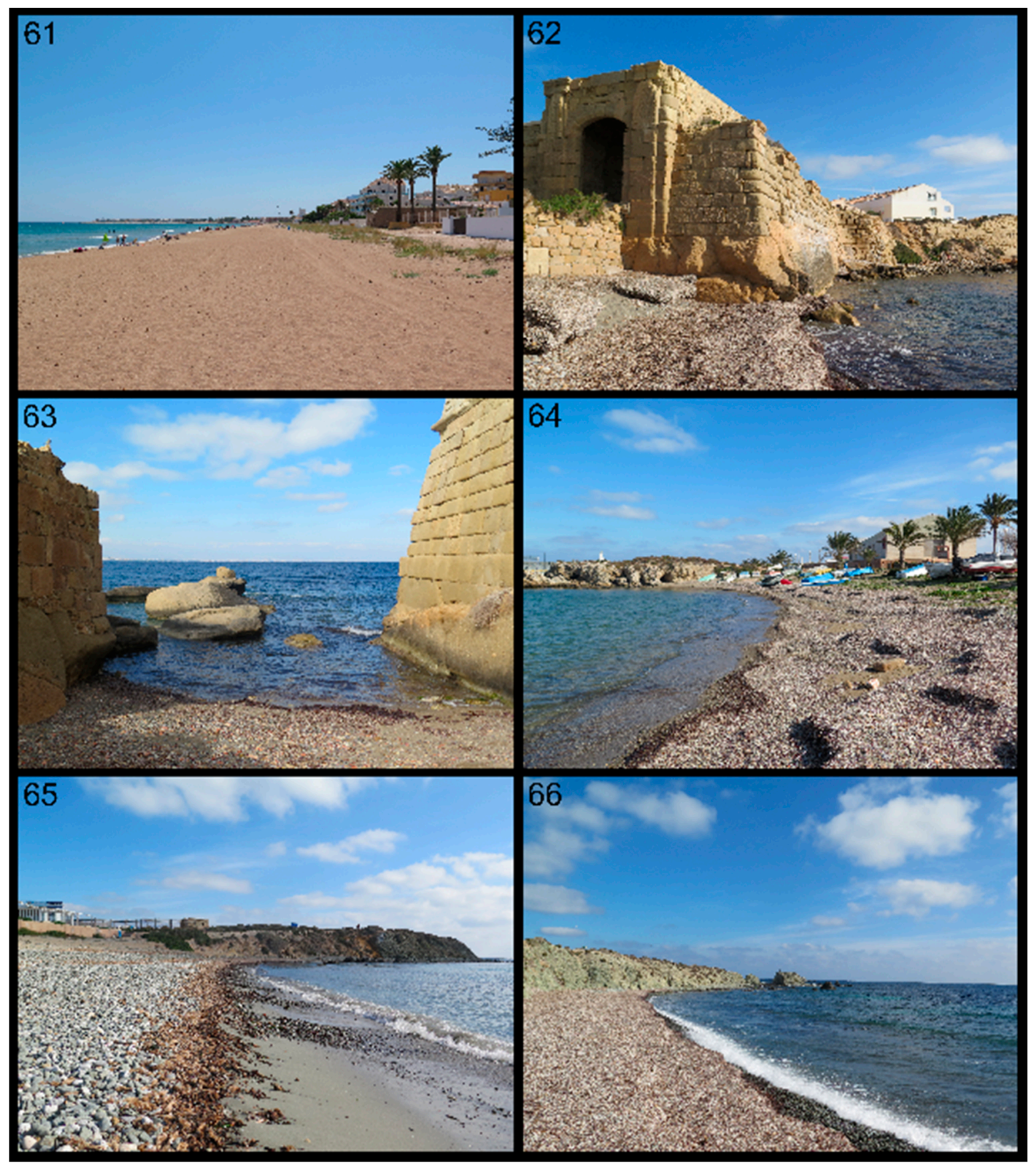

Figure A5. Beaches investigated: from “Racó de L'Alberca" (No. 61) to "Platja Gran” (No.66). 
Table A1. Coordinates in CIEL*a* $b^{*}$ colour space of the 66 investigated samples and percentage of sand grains by quartz (leucocratic component), rock fragments and shell fragments (melanocratic components). The three granulometry parameters most commonly used are included. See Figure 1 for number location.

\begin{tabular}{|c|c|c|c|c|c|c|c|c|}
\hline \multirow{2}{*}{ No. } & \multicolumn{3}{|c|}{ Colour Parameters } & \multicolumn{2}{|c|}{ Mineralogy } & \multicolumn{3}{|c|}{ Grain Size Parameters $(\mu \mathrm{m})$} \\
\hline & $L^{*}$ (D65) & $a^{*}(D 65)$ & $b^{*}$ (D65) & Leucocratic Comp. (\%) & Melanocratic Comp. (\%) & Mean & Mode & Median D50 \\
\hline 1 & 62.2 & 1.43 & 7.94 & 72.26 & 27.74 & 151.1 & 152.5 & 151.1 \\
\hline 2 & 61.65 & 2.26 & 10.95 & 57.92 & 42.08 & 185.2 & 152.5 & 161.2 \\
\hline 3 & 62.16 & 3.25 & 12.24 & 57.14 & 42.86 & 190.8 & 152.5 & 166.7 \\
\hline 4 & 62.41 & 2.95 & 12.17 & 50.59 & 49.41 & 152.5 & 152.5 & 152.5 \\
\hline 5 & 63.38 & 2.6 & 12 & 51.14 & 48.86 & 153.6 & 152.5 & 153.6 \\
\hline 6 & 64 & 4.03 & 14.52 & 53.91 & 46.09 & 193.2 & 152.5 & 169.8 \\
\hline 7 & 63.71 & 3.68 & 13.32 & 52.97 & 47.03 & 194.7 & 152.5 & 170.6 \\
\hline 8 & 57.06 & 1.48 & 8.37 & 50.00 & 50.00 & 149.2 & 152.5 & 149.2 \\
\hline 9 & 59.06 & 1.71 & 9.27 & 41.63 & 58.37 & 182.9 & 152.5 & 159.3 \\
\hline 10 & 56.7 & 2.01 & 10.08 & 43.10 & 56.90 & 153.8 & 152.5 & 153.8 \\
\hline 11 & 54.4 & 5.66 & 16.49 & 30.35 & 69.65 & 194.3 & 152.5 & 171.0 \\
\hline 12 & 57.02 & 3.32 & 13.36 & 29.62 & 70.38 & 150.9 & 152.5 & 150.9 \\
\hline 13 & 57.14 & 4.45 & 15.51 & 38.56 & 61.44 & 177.8 & 152.5 & 155.7 \\
\hline 14 & 57.19 & 5.53 & 16.01 & 25.10 & 74.90 & 233.8 & 302.5 & 269.0 \\
\hline 15 & 55.07 & 6.04 & 17.7 & 31.66 & 68.34 & 239.5 & 302.5 & 276.3 \\
\hline 16 & 57.33 & 4.39 & 16.07 & 28.90 & 71.10 & 150.1 & 152.5 & 150.1 \\
\hline 17 & 55.44 & 5.41 & 16.9 & 30.21 & 69.79 & 198.7 & 152.5 & 176.0 \\
\hline 18 & 55.54 & 4.95 & 16.29 & 39.02 & 60.98 & 189.6 & 152.5 & 162.3 \\
\hline 19 & 54.95 & 5.53 & 18.06 & 29.87 & 70.13 & 154.5 & 152.5 & 154.5 \\
\hline 20 & 54.9 & 4.59 & 14.89 & 33.84 & 66.16 & 224.7 & 302.5 & 253.3 \\
\hline 21 & 57.95 & 4.44 & 15.9 & 39.57 & 60.43 & 149.7 & 152.5 & 149.7 \\
\hline 22 & 55.43 & 4.3 & 14.02 & 44.49 & 55.51 & 199.9 & 302.5 & 180.0 \\
\hline 23 & 53.78 & 0.72 & 6.41 & 48.78 & 51.22 & 149.3 & 152.5 & 149.3 \\
\hline 24 & 55.9 & 2.02 & 9.76 & 48.47 & 51.53 & 151.3 & 152.5 & 151.3 \\
\hline 25 & 52 & 0.81 & 5.82 & 51.38 & 48.62 & 151.4 & 152.5 & 151.4 \\
\hline 26 & 55.78 & 4.3 & 15.19 & 40.08 & 59.92 & 152.6 & 152.5 & 152.6 \\
\hline 27 & 57.15 & 4.21 & 14.65 & 45.45 & 54.55 & 188.7 & 152.5 & 164.4 \\
\hline 28 & 54.48 & 5.27 & 16.21 & 32.74 & 67.26 & 236.2 & 302.5 & 272.4 \\
\hline 29 & 52.14 & 5 & 15.57 & 30.29 & 69.71 & 296.0 & 302.5 & 296.0 \\
\hline 30 & 58.52 & 2.6 & 11.6 & 52.22 & 47.78 & 181.8 & 152.5 & 157.8 \\
\hline 31 & 56.76 & 3.48 & 15.12 & 35.58 & 64.42 & 174.9 & 152.5 & 155.3 \\
\hline 32 & 57.11 & 3.11 & 14.46 & 40.27 & 59.73 & 232.5 & 152.5 & 258.9 \\
\hline 33 & 53.53 & 4.38 & 16.76 & 14.22 & 85.78 & 469.5 & 605.0 & 537.2 \\
\hline 34 & 58.41 & 2.83 & 9.85 & 48.12 & 51.88 & 193.0 & 152.5 & 166.2 \\
\hline 35 & 57.76 & 3.03 & 10.86 & 46.32 & 53.68 & 187.6 & 152.5 & 159.4 \\
\hline 36 & 58.41 & 3.73 & 12.57 & 56.28 & 43.72 & 234.0 & 302.5 & 269.8 \\
\hline 37 & 57.58 & 2.87 & 10.23 & 40.33 & 59.67 & 199.2 & 152.5 & 177.3 \\
\hline 38 & 56.79 & 3.09 & 11 & 46.15 & 53.85 & 232.7 & 302.5 & 266.0 \\
\hline 39 & 56.07 & 3.73 & 12.72 & 45.43 & 54.57 & 239.4 & 302.5 & 276.6 \\
\hline 40 & 54.26 & 5.55 & 17.54 & 8.08 & 91.92 & 904.3 & 605.0 & 682.0 \\
\hline 41 & 56.43 & 3.3 & 11.88 & 52.26 & 47.74 & 232.2 & 302.5 & 265.3 \\
\hline 42 & 51.92 & 4.86 & 14.65 & 15.00 & 85.00 & 386.1 & 302.5 & 331.9 \\
\hline 43 & 58.55 & 2.94 & 13 & 46.82 & 53.18 & 183.6 & 152.5 & 159.8 \\
\hline 44 & 58.85 & 3.58 & 12.84 & 58.72 & 41.28 & 176.9 & 152.5 & 156.3 \\
\hline 45 & 56.44 & 4.1 & 13.71 & 42.91 & 57.09 & 258.2 & 302.5 & 291.0 \\
\hline 46 & 56.75 & 2.93 & 11.02 & 46.75 & 53.25 & 191.0 & 152.5 & 163.7 \\
\hline 47 & 56.93 & 4.64 & 15.44 & 42.53 & 57.47 & 196.5 & 152.5 & 174.4 \\
\hline 48 & 53.62 & 2.48 & 12.06 & 28.23 & 71.77 & 151.5 & 152.5 & 151.5 \\
\hline 49 & 56.59 & 4.07 & 14.47 & 34.01 & 65.99 & 182.5 & 152.5 & 158.8 \\
\hline 50 & 57.23 & 2.71 & 13.07 & 33.33 & 66.67 & 180.5 & 152.5 & 157.5 \\
\hline 51 & 70.75 & 3.55 & 18.82 & 39.04 & 60.96 & 275.2 & 302.5 & 280.9 \\
\hline 52 & 51.88 & 2.16 & 10.81 & 22.85 & 77.15 & 176.0 & 152.5 & 155.8 \\
\hline 53 & 55.07 & 2.61 & 11.94 & 36.22 & 63.78 & 290.1 & 302.5 & 292.3 \\
\hline 54 & 54.77 & 5.41 & 16.44 & 10.00 & 90.00 & 624.0 & 605.0 & 615.2 \\
\hline 55 & 51.72 & 2.4 & 10.95 & 24.42 & 75.58 & 237.1 & 302.5 & 273.7 \\
\hline 56 & 56.55 & 1.29 & 8.57 & 66.79 & 33.21 & 189.6 & 152.5 & 167.6 \\
\hline 57 & 52.02 & 3.15 & 12.39 & 50.43 & 49.57 & 185.1 & 152.5 & 161.4 \\
\hline 58 & 47.66 & 5.16 & 15.32 & 29.44 & 70.56 & 292.6 & 302.5 & 292.6 \\
\hline 59 & 47.78 & 5.37 & 15.66 & 35.96 & 64.04 & 299.4 & 302.5 & 299.4 \\
\hline 60 & 46.91 & 5.69 & 15.19 & 19.90 & 80.10 & 572.2 & 605.0 & 559.0 \\
\hline 61 & 48.01 & 6.4 & 15.7 & 23.75 & 76.25 & 470.3 & 605.0 & 538.1 \\
\hline 62 & 45.95 & 1.16 & 8.14 & 12.81 & 87.19 & 380.3 & 302.5 & 330.7 \\
\hline 63 & 40.16 & 2.37 & 11.21 & 16.67 & 83.33 & 593.4 & 605.0 & 593.4 \\
\hline 64 & 46.03 & 2.26 & 12.73 & 21.33 & 78.67 & 464.1 & 605.0 & 534.1 \\
\hline 65 & 46.13 & -0.03 & 7.48 & 31.05 & 68.95 & 348.9 & 302.5 & 304.4 \\
\hline 66 & 45.54 & -1.47 & 8.93 & 19.70 & 80.30 & 605.0 & 605.0 & 605.0 \\
\hline
\end{tabular}


Table A2. Bivariate Pearson correlation matrix for the analyzed parameters. Relevant correlations marked in bold.

\begin{tabular}{cccccc}
\hline & $\mathbf{L}^{*}$ & $\mathbf{a}^{*}$ & $\mathbf{b}^{*}$ & Leucocratic Components & Melanocratic Components \\
\hline $\mathrm{L}^{*}$ & 1 & 0.058 & 0.119 & 0.624 & -0.624 \\
$\mathrm{a}^{*}$ & & 1 & 0.890 & -0.302 & 0.302 \\
$\mathrm{~b}^{*}$ & & & 1 & -0.402 & 0.402 \\
Leucocratic components & & & & 1 & -1 \\
Melanocratic components & & & & & 1 \\
\hline
\end{tabular}

\section{References}

1. Pranzini, E.; Vitale, G. Beach Sand Colour: The Need for a Standardised Assessment Procedure. J. Coast. Res. 2011, 61, 66-69. [CrossRef]

2. Roca, E.; Riera, C.; Villares, M.; Fragell, R.; Junyent, R. A combined assessment of beach occupancy and public perceptions of beach quality: A case study in the Costa Brava, Spain. Ocean. Coast. Manag. 2008, 51, 839-846. [CrossRef]

3. Pranzini, E.; Simonetti, D.; Vitale, G. Sand colour rating and chromatic compatibility of borrow sediments. J. Coast. Res. 2010, 26, 798-808. [CrossRef]

4. Ergin, A.; Karaesmen, E.; Micallef, A.; Williams, A.T. A new methodology for evaluating coastal scenery: Fuzzy logic systems. Area 2004, 36, 367-386. [CrossRef]

5. Rangel-Buitrago, N. Coastal Scenery: Evaluation and Management; Springer: Cham, Switzerland, 2018.

6. Asensio-Montesinos, F.; Anfuso, G.; Corbí, H. Coastal scenery and litter impacts at Alicante (SE Spain): Management issues. J. Coast. Cons. 2019, 23, 185-201. [CrossRef]

7. Peterson, C.H.; Bishop, M.J. Assessing the environmental impacts of beach nourishment. Bioscience 2005, 55, 887-896. [CrossRef]

8. Anfuso, G.; Williams, A.T.; Hernández, J.C.; Pranzini, E. Coastal scenic assessment and tourism management in western Cuba. Tour. Manag. 2014, 42, 307-320. [CrossRef]

9. Cárdenes, V.; Rubio, A. Measure of the color of beach nourishment sands: A case study from the Belgium coast. Trabajos de Geología 2015, 35, 7-18. [CrossRef]

10. Pranzini, E. Protection studies at two recreational beaches: Poetto and Cala Gonone beaches, Sardinia, Italy. In Beach Management; Williams, A.T., Micallef, A., Eds.; Earthscan publishers: London, UK, 2009; pp. 287-306.

11. Houston, J.R. The economic value of beaches-a 2013 update. Shore Beach 2013, 81, 3-11.

12. Aragonés, L.; López, I.; Villacampa, Y.; Serra, J.C.; Saval, J.M. New methodology for the classification of gravel beaches: Adjusted on Alicante (Spain). J. Coast. Res. 2014, 3, 1023-1034. [CrossRef]

13. Corbí, H.; Asensio-Montesinos, F.; Ramos-Esplá, A.A. The littoral bottoms of Benidorm Island (western Mediterranean Sea): Eco-sedimentological characterization through benthic foraminifera. Thalassas 2016, 32, 105-115. [CrossRef]

14. López, I.; López, M.; Aragonés, L.; García-Barba, J.; López, M.P.; Sánchez, I. The erosion of the beaches on the coast of Alicante: Study of the mechanisms of weathering by accelerated laboratory tests. Sci. Total Environ. 2016, 566, 191-204. [CrossRef] [PubMed]

15. Pagán, J.I.; Aragonés, L.; Tenza-Abril, A.J.; Pallarés, P. The influence of anthropic actions on the evolution of an urban beach: Case study of Marineta Cassiana beach, Spain. Sci. Total Environ. 2016, 559, 242-255. [CrossRef] [PubMed]

16. López, M.; Baeza-Brotons, F.; López, I.; Tenza-Abril, A.J.; Aragonés, L. Mineralogy and morphology of sand: Key parameters in the durability for its use in artificial beach nourishment. Sci. Total Environ. 2018, 639, 186-194. [CrossRef] [PubMed]

17. Pardo-Pascual, J.E.; Sanjaume, E. Beaches in Valencian Coast. In The Spanish Coastal Systems; Springer: Cham, Switzerland, 2019; pp. 209-236.

18. Pranzini, E. Il colore della sabbia: Percezione, caratterizzazione e compatibilità nel ripascimento artificiale delle spiagge. Studi Costieri. 2008, 15, 101-122.

19. Fernández-Fernández, S.; Bernabeu, A.M.; Rey, D.; Rubio, B.; Vilas, F. Determinación del color como herramienta de detección de contaminación por fuel en playas arenosas. Geogaceta 2011, 50, 165-168. 
20. Bigongiari, N.; Cipriani, L.E.; Pranzini, E.; Renzi, M.; Vitale, G. Assessing shelf aggregate environmental compatibility and suitability for beach nourishment: A case study for Tuscany (Italy). Mar. Pollut. Bull. 2015, 93, 183-193. [CrossRef]

21. Cárdenes, V.; Pedrosa, E.S. Propuestas de actividad didáctica para el estudio del, tamaño y composición de arenas de playa. Un caso práctico en la costa de Bélgica. Enseñanza de las Ciencias de la Tierra 2015, 23, 315.

22. Corbí, H.; Martínez-Martínez, J. Interpretando ambientes sedimentarios: Taller de sedimentología con arenas como actividad didáctica de Ciencias de la Tierra. Enseñanza de las Ciencias de la Tierra 2015, 23, 242.

23. Corbí, H.; Martínez-Martínez, J.; Martin-Rojas, I. Linking Geological and Architectural Heritage in a Singular Geosite: Nueva Tabarca Island (SE Spain). Geoheritage 2019, 11, 703-716. [CrossRef]

24. Gilabert, E.J. Medida del color; Universidad Politécnica de Valencia: Valencia, Spain, 1992; p. 177.

25. Comission Internationale de l'Eclairage. Recommendations on Uniform Color Spaces: Color-Difference Equations; Psychometric Color Terms; CIE Publication 15 Bureau Central de la CIE Paris: Paris, France, 1976.

26. Pranzini, E.; Anfuso, G.; Botero, C.M.; Cabrera, A.; Campos, Y.A.; Martinez, G.C.; Williams, A.T. Sand colour at Cuba and its influence on beach nourishment and management. Ocean. Coast. Manag. 2016, 126, 51-60.

27. Guedes, A.; Ribeiro, H.; Valentim, B.; Noronha, F. Quantitative colour analysis of beach and dune sediments for forensic applications: A Portuguese example. Forensic Sci. Int. 2009, 190, 42-51. [CrossRef] [PubMed]

28. Harris, A.C.; Weatherall, I.L. Geographic variation for colour in the sandburrowing beetle Chaerodes trachyscelides White (Coleoptera: Tenebrionidae) on New Zealand beaches analysed using CIELAB L* values. Biol. J. Linn. Soc. 1991, 44, 93-104. [CrossRef]

29. Tsujimoto, G.; Tamai, M. Analysis of beach sand colour and its application to sedimentation. In Proceedings of the 7th International Conference on Asian and Pacific Coasts (APAC 2013), Bali, Indonesia, 24-26 September 2013; pp. 141-146.

30. Estévez, A.; Vera, J.A.; Alfaro, P.; Andreu, J.M.; Tent-Manclús, J.E.; Yébenes, A. Geología de la provincia de Alicante. Enseñanza de las Ciencias de la Tierra 2004, 12, 2-15.

31. Alfaro, P.; Andreu, J.M.; Estévez, A.; Tent-Manclús, J.E.; Yébenes, A. Geología de Alicante; AEPECT-University of Alicante: Alicante, Spain, 2004.

32. Corbí, H.; Soria, J.M.; Lancis, C.; Giannetti, A.; Tent-Manclús, J.E.; Dinarès-Turell, J. Sedimentological and paleoenvironmental scenario before, during, and after the Messinian Salinity Crisis: The San Miguel de Salinas composite section (western Mediterranean). Mar. Geol. 2016, 379, 246-266.

33. Corbí, H.; Soria, J.M. Late Miocene-early Pliocene planktonic foraminifer event-stratigraphy of the Bajo Segura basin: A complete record of the western Mediterranean. Mar. Petrol. Geol. 2016, 77, 1010-1027.

34. Alfaro, P.; Andreu, J.M.; Estévez, A.; Pina, J.A.; Yébenes, A. Itinerarios Geológicos por la Provincia de Alicante; Publicaciones de la Universidad de Alicante: Alicante, Spain, 2008; p. 317.

35. Martínez-Martínez, J.; Corbí, H.; Martin-Rojas, I.; Baeza-Carratalá, J.F.; Giannetti, A. Stratigraphy, petrophysical characterization and 3D geological modelling of the historical quarry of Nueva Tabarca island (western Mediterranean): Implications on heritage conservation. Eng Geol. 2017, 231, 88-99. [CrossRef]

36. Díaz Orueta, F.; Lourés Seoane, M.L. La globalización de los mercados inmobiliarios: Su impacto sobre la Costa Blanca. CyTET 2008, XL, 77-92.

37. Ergin, A.; Williams, A.T.; Micallef, A. Coastal scenery: Appreciation and evaluation. J. Coast. Res. 2006, 22, 958-964. [CrossRef]

38. Botero, C.; Anfuso, G.; Williams, A.T.; Palacios, A. Perception of coastal scenery along the Caribbean littoral of Colombia. J. Coast. Res. 2013, 65, 1733-1739. [CrossRef]

39. Williams, A.T.; Rangel-Buitrago, N.G.; Anfuso, G.; Cervantes, O.; Botero, C.M. Litter impacts on scenery and tourism on the Colombian north Caribbean coast. Tour. Manag. 2016, 55, 209-224. [CrossRef]

40. El Naturalista Digital. Las playas del Parque Regional de los "Arenales" de San Pedro, en regresión por las actuaciones sobre los arribazones que las protegen. Available online: elnaturalistadigital.blogspot.com/2006/ 07/las-playas-del-parque-regional-de-los.html (accessed on 13 January 2020).

41. Diputación Provincial de Alicante. Senderos de la Arena. Guía de Playas de la Provincia de Alicante; Diputación de Alicante, Área de Medio Ambiente: Alicante, Spain, 2010; p. 248.

42. Gobierno de España. Ministerio para la Transición Ecológica. Guía de Playas. Available online: https: //www.miteco.gob.es/es/costas/servicios/guia-playas/ (accessed on 13 January 2020). 
43. Instituto Geográfico Nacional. Plano del fondeadero de Lugar Nuevo. Dirección Hidrográfica, Cádiz, 1813. Available online: http://www.ign.es/web/catalogo-cartoteca/resources/pdfcards/card009746.pdf (accessed on 13 January 2020).

44. Corbí, H.; Riquelme, A.; Megías-Baños, C.; Abellan, A. 3-D morphological change analysis of a beach with seagrass berm using a terrestrial laser scanner. ISPRS Int. Geo-Inf. 2018, 7, 234.

45. Pagán, J.I.; López, M.; López, I.; Tenza-Abril, A.J.; Aragonés, L. Study of the evolution of gravel beaches nourished with sand. Sci. Total Environ. 2018, 626, 87-95.

46. Bajoelagua. Bruselas denuncia a España por las regeneraciones de playas en Baleares y Alicante. Available online: www.bajoelagua.com/articulos/noticias-buceo/1385.htm (accessed on 13 January 2020).

47. Aragonés, L.; García-Barba, J.; García-Bleda, E.; López, I.; Serra, J.C. Beach nourishment impact on Posidonia oceanica: Case study of Poniente Beach (Benidorm, Spain). Ocean Eng. 2015, 107, 1-12. [CrossRef]

48. Diario Información. Benidorm desiste de cubrir "el llosar" de Levante con arena. Available online: www.diarioinformacion.com/benidorm/2012/02/05/benidorm-desiste-cubrir-llosar-levante-arena/ 1219915.html (accessed on 13 January 2020).

49. Diario Información. 8.000 toneladas de arena para paliar los efectos del temporal en Cala Fustera de Benissa. Available online: www.diarioinformacion.com/marina-alta/2017/03/21/8000-toneladas-arena-paliar-efectos/ 1874226.html (accessed on 13 January 2020).

50. Chiva, L.; Pagán, J.I.; López, I.; Tenza-Abril, A.J.; Aragonés, L.; Sánchez, I. The effects of sediment used in beach nourishment: Study case El Portet de Moraira beach. Sci. Total Environ. 2018, 628, 64-73. [CrossRef] [PubMed]

51. Alicante Plaza. Xàbia retira el dique de arena de la playa que se alzó para frenar el temporal. Available online: alicanteplaza.es/Xbiaretiraeldiquedearenadelaplayaquesealzparafrenareltemporal (accessed on 13 January 2020).

52. Aberasturi, A.; Acosta, J.; Aguilera, J.C.; Alfaro, P.; Andreu, J.M.; Antón, I.; Zaragozí, A. Geolodía 17. Alicante: Isla de Nueva Tabarca 2017, 7, 43.

53. Blott, S.J.; Pye, K. GRADISTAT: A grain size distribution and statistics package for the analysis of unconsolidated sediments. Earth Surf. Process. Landf. 2001, 26, 1237-1248. [CrossRef]

54. Folk, R.L.; Ward, W.C. Brazos River bar: A study in the significance of grain size parameters. J. Sed. Petrol. 1957, 27, 3-26. [CrossRef]

55. Williams, A.T.; Micallef, A. Beach Management. Principles and Practice; Earthscan: London, UK, 2009 ; p. 480.

56. González-Correa, J.M.; Fernández-Torquemada, Y.; Sánchez-Lizaso, J.L. Short-term effect of beach replenishment on a shallow Posidonia oceanica meadow. Mar. Environ. Res. 2009, 68, 143-150.

57. López-Andrés, L. La Regeneración de las playas de San Juan y Muchavista en 1991. Available online: http://www.alicantevivo.org/2008/06/la-regeneracin-de-las-playas-de-san.html (accessed on 22 November 2019).

58. Tenza-Abril, A.J.; Pagán, J.I.; Aragonés, L.; Saval, J.M.; Serra, J.C.; López, I. 60 years of urban development in Denia and its influence on the Marineta Cassiana beach. Int. J. of Sust. Dev. Plan 2017, 12, 678-686. [CrossRef]

59. Bricio Garberí, L.; Negro Valdecantos, V.; Diez Gonzalez, J.J.; López Gutiérrez, J.S. Diseño funcional y ambiental de diques exentos de baja cota de coronación. Ing. Civ. 2010, 158, 53-61.

60. Martínez-Medina, A. Arquitectura del boom turístico (1953-1979). In El turismo en Alicante y la Costa Blanca Canelobre 2016, 66, 166-185.

61. Delgado, J.; Casado, C.L.; Estevez, A.; Giner, J.; Cuenca, A.; Molina, S. Mapping soft soils in the Segura river valley (SE Spain): A case study of microtremors as an exploration tool. J. Appl. Geophys 2000, 45, 19-32. [CrossRef]

62. Gilabert, E.; Martínez-Verdú, F. Medida de la luz y el color. Tomo 2: Aplicaciones; Valencia: Servicio de Publicaciones de la Universidad Politécnica de Valencia: Valencia, Spain, 2007; p. 251.

63. Martínez-Martínez, J.; Pola, A.; García-Sánchez, L.; Reyes Agustín, G.; Osorio Ocampo, L.S.; Macías Vázquez, J.L.; Robles-Camacho, J. Building stones used in the architectural heritage of Morelia (México): Quarries location, rock durability and stone compatibility in the monument. Environ. Earth Sci. 2018, 77, 167-182. [CrossRef]

64. Batalla, R.J. Sediment deficit in rivers caused by dams and instream gravel mining. Are view with examples from NE Spain. Rev C. \& G. 2003, 17, 79-91. 
65. Liquete, C.; Canals, M.; Arnau, P.; Urgeles, R.; Durrieu de Madron, X. The impact of humans on strata formation along Mediterranean margins. Oceanography 2004, 17, 70-79. [CrossRef]

66. Giannetti, A.; Monaco, P.; Falces-Delgado, S.; La Iacona, F.G.; Corbí, H. Taphonomy, ichnology, and palaeoecology to distinguish event beds in varied shallow-water settings (Betic Cordillera, SE Spain). J. Iber Geol. 2019, 45, 47-61. [CrossRef]

67. Cuevas-González, J.; Díez-Canseco, D.; Alfaro, P.; Andreu, J.M.; Baeza-Carratalá, J.M.; Benavente, D.; Blanco-Quintero, I.; Cañaveras, J.C.; Corbí, H.; Delgado, J.; et al. Geogymkhana-Alicante (Spain): Geoheritage through Education. Geoheritage 2020, (in press).

68. Ayuntamiento de Alicante. Alicante en los años 30. Exposición en el archivo municipal. Available online: https://www.alicante.es/es/agenda/alicante-anos-30-exposicion-archivo-municipal (accessed on 13 January 2020).

69. Pinterest. Playa de San Juan en los años 60, Alicante, España. Available online: https://www.pinterest.es/pin/ 450782243935888731/?lp=true (accessed on 9 January 2020).

70. Biroupeplaja. Available online: http://www.biroupeplaja.ro/plaja-san-juan-din-alicante-spania-villa-royal/ (accessed on 9 January 2020).

71. Diario Información. Pilar de la Horadada regenera sus playas con más de 30000m3 de arena. Available online: https://www.diarioinformacion.com/vega-baja/2015/07/07/playas-pilar-han-sidoregeneradas/1653097.html (accessed on 9 January 2020).

72. La crónica independiente. Las playas del Pilar han sido regeneradas con más de $30.000 \mathrm{~m}^{3}$ de arena, "el doble que otros años". Available online: http://lacronicaindependiente.com/2015/07/las-playas-del-pilarhan-sido-regeneradas-con-mas-de-30-000-m3-de-arena-el-doble-que-otros-anos/ (accessed on 9 January 2020).

(C) 2020 by the authors. Licensee MDPI, Basel, Switzerland. This article is an open access article distributed under the terms and conditions of the Creative Commons Attribution (CC BY) license (http://creativecommons.org/licenses/by/4.0/). 